\title{
The IMF in a World of Private Capital Markets
}

\author{
Barry Eichengreen, Kenneth Kletzer, and Ashoka Mody ${ }^{1}$
}

Revised, February 21, 2005

\begin{abstract}
The IMF attempts to stabilize private capital flows to emerging markets by providing public monitoring and emergency finance. In analyzing its role we contrast cases where banks and bondholders do the lending. Banks have a natural advantage in monitoring and creditor coordination, while bonds have superior risk sharing characteristics. Consistent with this assumption, banks reduce spreads as they obtain more information through repeat transactions with borrowers. By comparison, repeat borrowing has little influence in bond markets, where publicly-available information dominates. But spreads on bonds are lower when they are issued in conjunction with IMF-supported programs, as if the existence of a program conveyed positive information to bondholders. The influence of IMF monitoring in bond markets is especially pronounced for countries vulnerable to liquidity crises.
\end{abstract}

JEL Classification: F0, F2

\footnotetext{
${ }^{1}$ The authors are with the University of California, Berkeley; the University of California, Santa Cruz; and the International Monetary Fund, respectively. The views expressed are those of the authors and should not be attributed to the IMF or any other organization. We are grateful to Enrica Detragiache, Raghuram Rajan, and an anonymous referee for helpful comments and to Adrian de la Garza for carefully assembling a complex data set. Kletzer also thanks the Center for Pacific Basin Studies at the Federal Reserve Bank of San Francisco for partly supporting his research for this paper.
} 


\section{Introduction}

Catalyzing private capital flows to emerging markets has been an objective of the International Monetary Fund since at least the 1990s. ${ }^{2}$ The Fund provides public monitoring services and negotiates programs that enable borrowers to reveal their commitment to sound macroeconomic policies. In addition, its own lending may stabilize capital flows by providing bridge finance for creditworthy countries experiencing liquidity crises, the resolution of which may be difficult to coordinate for atomistic lenders.

In this paper we seek to better understand the roles of IMF monitoring and lending and provide new evidence of their effects. We analyze the impact of IMFsupported programs on market access and the cost of funds, building on three insights.

- $\quad$ First, if banks engage in monitoring as part of their normal operation, then IMF monitoring should have a relatively limited impact when bank syndicates do the lending.

- Second, private capital flows should be particularly sensitive to the magnitude of IMF financial commitments when the likelihood of debt restructuring is high.

- $\quad$ Third, precautionary programs are a mechanism through which governments can use their relationship with the IMF to signal their commitment to strong policies. Differences in the impact of precautionary and regular IMF programs should therefore be useful for distinguishing between the Fund's monitoring and lending roles.

\footnotetext{
${ }^{2}$ See for example IMF (1999).
} 
Our analysis is based on more than 6,700 loan transactions between emerging market borrowers and international bank syndicates and some 3,500 new bond issues placed between 1991 and 2002. We analyze the frequency of transactions and the spreads charged. Among the explanatory variables are (a) a measure of repeat borrowing that proxies for creditor learning about borrower characteristics and (b) the existence and size of IMF programs. Because we analyze individual transactions rather than aggregate capital flows or other macroeconomic conditions, our findings are less susceptible to causality running from the outcome to the decision to initiate an IMF program. ${ }^{3}$

Important differences between bank loans and bond issues have been documented in the domestic context. ${ }^{4}$ Banks act as delegated monitors on behalf of investors who cannot easily observe and discipline borrowers (Diamond 1984). The information they acquire can be used to limit the use of funds and in pricing loans. In contrast, individual bondholders lack the incentive to incur the costs of securing expensive private information about borrowers. Instead, public information—for example, the information assembled by credit rating agencies—dominates the market for debt securities.

Securitized debt instruments, on the other hand, have superior risk-sharing characteristics. Credit risk can be diversified away, in part, by spreading individual loans across investors and enabling them to hold diversified portfolios. Banks cannot engage in this practice to the same extent without eroding their incentive to invest in dedicated

\footnotetext{
${ }^{3}$ High-frequency data also allow us to capture the timing of programs more precisely than is possible in aggregate studies using annual data to analyze the influence of IMF programs.

${ }^{4}$ This difference between bank and capital markets has been well documented in the domestic US context (see, for example, Fama 1985 and James 1987).
} 
monitoring technologies. This tradeoff is a way of understanding why lending takes place through both banks and bond markets.

Banks can also more easily coordinate in response to default and restructuring. They are relatively few in number and contractual arrangements such as sharing clauses reduce the incentive to hold out. The advantages of creditor coordination may make it even more profitable for banks to monitor borrowers, as we explain below. Thus, it is not necessary to assume that banks have intrinsically superior monitoring ability; they may simply have more incentive to invest in gathering and using relevant information.

Eichengreen and Mody (1998) find that spreads on syndicated loans fall with the number of loans extended to a borrower. An interpretation is that contact through repeat borrowing informs creditors about borrower characteristics, reducing uncertainty and risk premia. That earlier paper did not also consider repeat borrowing in bond markets. We do so here, hypothesizing that this effect is stronger for bank loans than bonds because coordination allows banks to make better use of any information thereby gleaned.

The other potential monitor is the IMF. ${ }^{5}$ By putting a program in place, the Fund may be able to acquire information not also available to the private sector or acquire it at lower cost. Indeed, the Fund may convey information to the markets when it does not have superior monitoring technology. Negotiating an IMF program may simply be a way for a government to signal its type. ${ }^{6}$ Imagine that the standard conditions attached to

\footnotetext{
${ }^{5}$ As posited by Tirole (2002), Mody and Saravia (2003) and Bordo, Mody, and Oomes (2004).

${ }^{6}$ Bordo, Mody, and Oomes (2004) have argued that the IMF's monitoring role does not imply that the Fund has better information than the market. As such, the Fund adds value not through the mere signaling of new information. Rather, the Fund can monitor commitment to a policy program (see also Mody and Saravia 2003). In practice it is difficult to distinguish if it is content of the program or the monitoring that is relevant.
} 
Fund programs are easier to satisfy for either economic or political reasons by governments truly committed to strong policies and that violating that conditionality has significant costs. Then a country with strong policies will be more likely to sign up for a program, signaling its type and lowering its spreads.

A special case in point is when an IMF lending arrangement is converted into a precautionary program. ${ }^{7}$ A country then volunteers to not draw on IMF resources while still allowing itself to be subjected to Fund monitoring and conditionality. ${ }^{8}$ The Fund's monitoring should be particularly important for bond markets not inhabited by a small number of large investors (banks) prepared to individually invest in ascertaining the government's type. At the same time, IMF lending, by reducing the probability of default, could nullify the creditor coordination advantage of banks.

Consistent with these hypotheses, we find that repeat borrowing is more important in reducing the costs of borrowing from bank syndicates than bond markets. In contrast, public monitoring through IMF programs has a larger impact on spreads in markets dominated by bonds than bank loans, again consistent with our priors. But the IMF's presence and lending have different effects on countries in different situations. For countries with external debt/GDP ratios below 60 per cent range, it is the IMF's presence, as distinct from its lending, that matters for bond market access. We interpret this as consistent with arguments emphasizing the Fund's monitoring and signaling roles. As

However, because we do observe that programs (with widely varying conditionality) reduce bond interest rate spreads, it is possible to argue that the monitoring that accompanies the core conditionality in all IMF programs helps creditors gain confidence in the likelihood of reduced policy variability.

${ }^{7}$ For more discussion of the channels through which IMF programs can influence international capital flows, see Cottarelli and Giannini (2002) and Bordo, Mody, and Oomes (2004).

${ }^{8}$ Although the financial support can still become available should the need arise. 
debt rises from there, IMF presence is still associated with lower spreads but to a diminishing extent. The impact of IMF presence disappears when debt reaches 70 percent of GDP. Moreover, there is little evidence in this high debt range that additional IMF lending reduces spreads and enhances market access. For countries in this range, neither IMF presence nor IMF lending significantly enhances market access. Evidently, countries with such high debts have deep structural problems that must be solved before IMF intervention can catalyze external finance. Only programs that turn precautionary that is, where the outlook improves sufficiently that the country can voluntarily choose to stop drawing on Fund resources - have a significant negative impact on borrowing costs at high debt levels. This finding is again consistent with our arguments regarding country signaling and IMF monitoring.

The next section develops the theoretical background to these issues. The two sections following that then provide evidence on differences in international lending through bank loans and bond markets. We then analyze the factors that go into the decision to borrow and the further choice between loans and bonds. The results confirm that IMF programs do more to facilitate bond issuance than bank lending. Finally, we document the importance for the pricing of loans and bonds of private monitoring in bank lending and of public monitoring through IMF programs in bond markets.

\section{Theoretical Background}

Our theoretical discussion focuses on sovereign default, renegotiation, and endogenous problems of liquidity in highlighting the IMF's monitoring and creditorcoordination roles. Our point of departure, following Eaton and Gersovitz (1981), Bulow 
and Rogoff (1989), and Kletzer and Wright (2000), is that lenders and borrowers take into account the risk of default when agreeing to the terms of a debt contract. Changes in this risk will therefore be reflected in the volume of debt and interest rates. Our discussion is also informed by Tirole's (2002) exposition of dual and common agency problems in the context of international financial contracts. As Tirole notes, the government may become an agent even when the debt contract is between private borrowers and lenders, since government actions bear on a private debtor's ability to repay. Private debt can have sovereign risk as a result of explicit or implicit government guarantees and/or a debtor's recourse to domestic legal protection. We therefore assume that the envelope of resources and government policies determines the ability and willingness of the government and private creditors to repay. ${ }^{9}$

The logic of our argument can be summarized as follows. First, country fundamentals and government policies determine the ability and willingness of the government and private creditors to service their debts. This implies that the probability of default rises only after a threshold level of debt is reached, at which point access to credit markets weakens and spreads on new loans begin to rise. ${ }^{10}$ Second, in the presence of asymmetric information about borrower preferences, the ability of creditors to monitor debtors and make use of information will influence market behavior and outcomes. Creditor monitoring matters when debt restructuring can occur-in other words, it matters for countries with high debt levels and low credit ratings. A monitoring

\footnotetext{
${ }^{9}$ Even if a private borrower derives no protection from its home government's sovereignty, the analytics apply to any debtor that faces bounded penalties for defaulting. ${ }^{10}$ For low debt levels, an increase in debt may indicate improving fundamentals and thus result in narrower spreads, as suggested by Pattillo et al (2003).
} 
advantage can arise not just when some creditors are better informed than others but also when some creditors more readily respond to common information. ${ }^{11}$

An implication is that creditors with a monitoring advantage will tend to lend in markets where the return to monitoring is high, and conversely. When banks have a monitoring advantage, information about the debtor's policy preferences will affect terms on bank loans and bonds. IMF programs can also reveal and provide confidence in debtor government policies, reducing the common agency problem, but providing information can also reduce the advantage of private monitoring. Monitoring differences will also affect returns to learning about the debtor.

To further develop these points, we utilize a simple framework in which the debtor's resources are stochastic and all debt claims have the same maturity and priority. The debtor is willing to repay a maximal amount, $\mathrm{V}(\mathrm{y})$, in expected present value, in equilibrium. $\mathrm{V}(\mathrm{y})$ is the value of repaying in a forward-looking equilibrium that takes account of opportunities to renegotiate debt in the future. It is increasing in the fundamental, y. For strong fundamentals, y, or low levels of debt, V(y) exceeds D, and the debtor will repay. If, however, the outstanding debt, D, exceeds V(y), then the debtor is unwilling to meet its obligations and will seek to renegotiate.

When borrowing and repayment are repeated over time, the debtor's willingness to pay can be written as

$$
V\left(y_{t}\right)=w\left(y_{t}\right)+\frac{1}{1+r} E_{t} V_{t+1},
$$

${ }^{11}$ For example, banks can have a comparative advantage in creditor coordination in the context of debt renegotiation (when there are advantages to getting all creditors to take the same position). They may also be in a relatively favorable position to arrange concerted lending and thus control strategic uncertainty that can cause liquidity crises. 
where $w\left(y_{t}\right)$ indicates the debtor's equilibrium willingness to service debt today. An interpretation is that $w\left(y_{t}\right)$ represents the debtor's liquid resources and $V_{t+1}$ measures solvency. Under perfect information, current debt service obligations that cannot be met by the debtor $\left(D_{t}>V\left(y_{t}\right)\right)$ will be rolled over into new loans, while debts that will not be repaid in present value will be renegotiated.

The expected net return to creditors is given by

$$
E R_{t}=E\left(V_{t}: V\left(y_{t}\right) \leq D_{t}\right) \operatorname{Pr}\left(V\left(y_{t}\right) \leq D_{t}\right)+D_{t} \operatorname{Pr}\left(V\left(y_{t}\right)>D_{t}\right)-(1+r) D_{t},
$$

where $r$ is the return on alternative investments. The interest rate spread will be the difference between $E R_{t} / D_{t}$ and (1+r). This spread is increasing with the level of debt for positive probabilities that $V\left(y_{t}\right)$ is less than $D_{t}$. When the level of debt is low, this probability can be zero, in which case the spread does not rise with indebtedness. But as indebtedness rises further, the probability of default becomes positive, as does the risk premium. Models of debt renegotiation with perfect information thus imply that spreads will not increase with debt at low debt-to-GDP ratios but that they will start rising at an accelerating rate after the debt-to-GDP ratio passes a critical threshold. This is corroborated by our empirical work, below.

To motivate the role of monitoring, it is necessary to introduce information asymmetries. Assume that the debtor's willingness to pay is known by others with uncertainty. Specifically, suppose that lenders only know the distribution of the debtor's willingness to pay, $V\left(y_{t}\right)$, within an interval, $\left[V\left(y_{t}\right), \bar{V}\left(y_{t}\right)\right]$. For simplicity, the distribution can be taken as uniform around a mean equal to $V\left(y_{t}\right)$. The debtor can offer repayment, $\hat{V}\left(y_{t}\right)$, less than its true willingness to repay. Consistent with standard 
analyses, the equilibrium offer accepted by lenders yields repayment, $\hat{V}\left(y_{t}\right)$, equal to the debtor's actual willingness to pay when this equals its minimum value, $\underline{V}\left(y_{t}\right)$. For larger realizations of $V\left(y_{t}\right)$, the debtor will transfer less than its true willingness to pay and realize a positive surplus given by the difference, $V\left(y_{t}\right)-\hat{V}\left(y_{t}\right)$.

The debtor pays in full if $\hat{V}\left(y_{t}\right) \geq D_{t}$. Because actual repayments are less than the debtor's true capacity, the probability of default is higher and creditors' expected returns are lower when information is asymmetric.

Creditors can extract more surplus if monitoring helps them to become better informed about the debtor's future policy actions. Monitoring increases willingness to pay, raising returns in the event of renegotiation and reducing the probability that renegotiation occurs. If lenders learn about the characteristics of borrowers from repeat lending, as appears to be the case from the evidence reported below, then spreads should fall with repeat transactions. Similarly, if the IMF has an advantage in monitoring the policy actions of the debtor, then agreement to establish an IMF program should reduce spreads and increase debt issuance for a debtor with a positive probability of having to renegotiate.

Our empirical analysis in Section 5 below points to differences in the impact of repeat lending and IMF programs on bank loans and bond spreads. ${ }^{12}$ An explanation consistent with our findings is that banks and bondholders have different monitoring abilities. Banks will cater to smaller, less well established borrowers, since they presumably possess a superior monitoring technology. Bondholders will focus on large,

\footnotetext{
${ }^{12}$ See Section 5 below.
} 
well-known borrowers. ${ }^{13}$ The private information revealed by clients to their banks will then make more precise the bankers' views of their capacity to repay. On the other hand, if banks have a monitoring advantage over bondholders, then an improvement in public information resulting from an IMF program could reduce (or in the limit remove) that informational advantage, reducing bond spreads and encouraging bond issuance relative to bank loans.

With asymmetric information, the adoption of an IMF program can reveal information to capital markets about country policies and willingness to pay. This does not hinge on the assumption that the IMF has superior ability to collect or interpret data; the Fund may simply have the ability to commit to actions to which private investors cannot or will not commit. ${ }^{14}$ To the extent that the IMF has a superior ability to commit or objectives that differ from those of private investors, adoption of a Fund program can also reveal information about the debtor country. In turn this allows the government to signal its intentions. ${ }^{15}$ For example, the conditionality associated with an IMF loan might be less onerous for governments for which policy reforms are less costly, thus making it incentive compatible for such governments to sign up with the Fund in order to signal its type. Countries with stronger policies or a greater will to enact policy reform are thus able to reveal this information by negotiating a Fund agreement. Of course, adopting a

\footnotetext{
${ }^{13}$ See Petersen and Rajan $(1994,1995)$ for U.S. evidence consistent with this pattern.

${ }^{14}$ It should be possible to model the IMF as endogenously gaining a monitoring advantage through its ability to commit to lend only in a crisis in a repeated game. The approach of self-enforcing equilibrium taken by Kletzer and Wright (2000) in the sovereign debt context could be used to model de facto IMF seniority and why countries might meet IMF conditionality.

${ }^{15}$ Marchesi and Thomas 1999 offer a model in which Fund conditionality serves as a screening device.
} 
program may also reveal poor fundamentals, and not just a superior capacity to enact policy reforms, resulting in an overall ambiguous impact on spreads.

IMF programs sometimes turn precautionary: borrowing stops, but the government continues paying a commitment fee that gives it the option to resume borrowing. By turning a program precautionary, the debtor country government can thus reveal that it has a diminished need for official finance but a continuing commitment to prudent policies. This good news should be reflected in a reduction in spreads on both bank loans and bonds.

Debt restructuring can also give rise to differences between banks and bondholders if the members of a bank syndicate can more easily coordinate their actions. Recall that equation (1) separates current willingness to pay into the sum of current resources available for repayment $w\left(y_{t}\right)$ and discounted expected future willingness to pay. If coordination failures prevent bondholders from restructuring debts quickly, then banks can move first and secure a larger share of the pie. They can do so even when all creditors have identical information and learn at the same time that the debt is unsustainable. Recall that

$$
D_{t}=B_{t}+L_{t}>w\left(y_{t}\right)+\frac{1}{1+r} E_{t} V_{t+1}
$$

where $B_{t}$ and $L_{t}$ are outstanding bonds and bank debt, respectively. Banks can reschedule their loans and avoid immediate default by reducing repayments currently due while at the same time increasing future repayments by rolling over their loans at higher interest rates. Subsequent renegotiations incorporating equal sharing between bondholders and bank lenders will then divide the settlement amount between banks and 
bondholders on the basis of the new bank share of the total debt. To illustrate, let the banks reschedule an amount $\Delta L_{t}$ of current debt repayments so that

$$
w\left(y_{t}\right)=r^{b} B_{t}+r^{l} L_{t}-\Delta L_{t},
$$

where $r^{b} B_{t}$ and $r^{l} L_{t}$ are interest payments due on bonds and loans, respectively. The banks then increase loans in period $\mathrm{t}+1, L_{t+1}$, by an amount $r^{\prime} \Delta L_{t}$. The banks' share of future repayments rises to

$$
\left(\frac{L_{t+1}+\Delta L_{t}}{B_{t+1}+L_{t+1}+\Delta L_{t}}\right) V_{t+1}
$$

Since the increase in the value of bank claims comes out of the expected returns to bondholders in the event that current total debt is unsustainable, the interest rate $r^{\prime}$ can then be chosen to maximize the increase in expected returns,

$$
E_{t}\left(\frac{B_{t+1} \Delta L_{t}}{\left(B_{t+1}+L_{t+1}+\Delta L_{t}\right)\left(B_{t+1}+L_{t+1}\right)} V_{t+1}\right)-(1+r) \Delta L_{t}
$$

If the banks can reschedule a sufficient share of their debt, they can eliminate their current expected loss at the expense of bondholders. This strategic advantage contrasts with a simple principal-agent model in which improved monitoring by banks raises the probability of repayment and returns to banks and bondholders alike. ${ }^{16}$

The banks' strategic advantage can be reduced or eliminated by the presence of a more senior official-sector creditor. Since the first-mover advantage arises from the prospect of default, it can be reduced by availability of official support under an IMF program, assuming that such funding reduces the risk of renegotiation. Absent

${ }^{16}$ The sharing of negotiated repayments here contrasts with the assumptions of Bolton and Jeanne (2003) that bonds are not renegotiable but bank loans are and separate penalties apply in selective defaults. 
differences in bank and bond markets, the basic model of sovereign debt renegotiation with asymmetric information would imply that IMF monitoring and financial resources lead to equivalent reductions in bond and bank loan interest spreads. ${ }^{17}$ Similarly, if IMF conditionality improves fundamentals and growth prospects, then both bond and bank lending should increase. However, if banks have a monitoring advantage and can better manage creditor coordination and debt restructuring problems, as assumed here, then IMF monitoring that reveals debtor characteristics and IMF lending that reduces the likelihood of default will benefit bondholders more than banks.

Finally, we consider the role of liquidity crises, adapting the model of Morris and Shin (2003). ${ }^{18}$ In their model, the fundamental has a distribution that is public knowledge, but each lender in a continuum receives a privately observed noisy signal of its realization in the current period. ${ }^{19}$ In this setting, private information can generate coordination failures and produce liquidity crises even when debt is sustainable.

We reinterpret their model by distinguishing between banks and bondholders, assuming that banks coordinate whereas bondholders do not. If $V\left(y_{t}\right)$ exceeds total debt but the country's current liquid resources fall short of current net payments due, then a liquidity crisis is possible. When debtor liquidity falls below a critical level, bondholders facing uncertainty about one another's actions will be unwilling to purchase new bond

${ }^{17}$ Gai and Vause 2003 present a model in which the IMF acts as a delegated monitor motivated by private creditor coordination failures. Our emphasis on asymmetric private abilities to coordinate is different.

${ }^{18}$ Similar models by Rochet and Vives (2001) and Corsetti, Dasgupta, Morris and Shin (2001) also take a global games approach to catalytic finance. Chui, Gai and Haldane (2002) also discuss the policy implications of sovereign liquidity crises.

${ }^{19}$ Morris and Shin also distinguish short-term debt that amortizes in the current period from other debt. 
issues to replace amortizing debt. ${ }^{20}$ This may give rise to an incipient crisis. That crisis may be prevented, however, if bank syndicates replace the maturing bonds with additional bank loans.

Banks are able to do this, in principle, because they can coordinate among themselves. Suppose that banks observe both a private signal drawn from the same distribution as that of bondholders and the failure of the debtor to place new bond issues. They can then halt a liquidity-driven crisis by replacing the maturing bonds with news loans. They can move after bondholders exit and have an incentive to do so in order to avoid unnecessary defaults on their long-term loans. Such models thus imply that bank loans and bond issues should be negatively correlated if crises are caused by illiquidity.

Two further implications follow. First, a deterioration in market liquidity or increased uncertainty that reduces bond issuance can be mitigated by the presence of bank lending, since banks have an incentive to fill the gap. Second, the IMF, as lender in a liquidity crisis, can help to avoid costly default and renegotiation. ${ }^{21}$ Assume that potential purchasers of bonds are as poorly informed about what banks will do as they are about what other bondholders will do. Banks move on the basis of private information and the reluctance of bondholders to reenter the market. But both bondholders and banks should be able to anticipate the IMF's strategy when a program is in place. Then the existence of an IMF program should raise bond issuance relative to bank lending for countries susceptible to liquidity-driven crises. We examine this proposition empirically below.

\footnotetext{
${ }^{20}$ Morris and Shin (2003) detail the determination of the critical level of liquidity. For our interpretation, we leave out additive debtor effort in their model.

${ }^{21}$ Jeanne (2001) among others discusses the lender of last resort role of the IMF.
} 


\section{The Setting}

Although international lending through bond markets was prominent in the late $19^{\text {th }}$ and early $20^{\text {th }}$ centuries, from the 1960 s through the 1980 s private credit flows to developing and emerging economies took place mainly through banks. Lending via bond markets was about 10 percent of bank lending in the 1970s and early 1980s (Edwards 1986). This changed following the debt crises of the 1980: between 1991 and 2002, credit obtained via banks and bonds was of about the same order of magnitude, just under $\$ 700$ billion through each channel (Table 1$).^{22}$

Differences persisted, however, in the characteristics of the typical bank loan and bond. To show this, for each loan and bond in our data set we extracted the initial price, the initial maturity, the amount, and the currency of denomination. Borrowers are distinguished as sovereign, non-sovereign but public sector, and private sector. ${ }^{23}$ On average, bank loans are more numerous and smaller. Between 1991 and 2002, Loanware reports 6,747 Libor-based syndicated loan transactions; during the same period, Bondware reports the issuance of just over 3700 bonds. ${ }^{24}$ On average, a bond issue was about 70 percent larger than a loan transaction.

\footnotetext{
${ }^{22}$ While we include all bonds issued in our analysis, we restrict the sample of loans to those that were priced based on Libor. These form the vast majority of international syndicated loans, both in terms of numbers and in the amount borrowed. By limiting the loans to those priced off Libor, we believe that more precise estimates of loan pricing become possible.

${ }^{23}$ We use these distinctions to also construct an estimate of the numbers that did not borrow. Thus, for a given country in a given quarter, the absence of borrowing by the sovereign implied that the sovereign had either forgone the opportunity to borrow or had not had access to international funds. Similarly, we identify country-quarters where no public (non-sovereign) and private borrowing occurred. For more on this, see below. ${ }^{24}$ Of which spreads are available for about 3500
} 
We construct a measure of repeat borrowing, $R$, separately for bank and bond borrowing. Starting with January 1, 1991, the measure takes the value 1 the first time a borrower enters into an international debt contract. With each subsequent instance of borrowing we then increment the value of $R$ by one. The results show that repeat borrowing is more common in bond markets, where the median number of borrowings over the period 1991 to 2002 is 3 (the $75^{\text {th }}$ percentile is 8 and the $90^{\text {th }}$ percentile is 27 ); for banks, the median is 2 (the $75^{\text {th }}$ percentile is 4 and the $90^{\text {th }}$ percentile is 8 ). Thus, compared with banks, which allow a diverse set of clients to episodically borrow, the bond market caters to borrowers with name recognition who return frequently.

Relative to bank loans, bonds were more likely to be issued when the issuing country had an IMF-supported program. About 22 percent of loans were contracted when a country had a Fund program in place (Table 2). In contrast, just over a third of bonds were issued in the presence of a program. To put the point another way, when countries were under an IMF program they were about as likely to borrow through a loan or a bond, but a loan was more than twice as likely when there was no program.

While IMF programs appear to shift borrowing toward bonds, this shift does not occur uniformly. Table 2 shows that countries with external-debt-to-GDP ratios below 30 percent had few bond or loan transactions while under IMF programs. When the debtratio was between 30 and 40 percent, more borrowing occurred under IMF programs, especially through bonds; however, the number of credit contracts was still higher in countries without, rather than with, IMF programs. Countries with debt/GDP ratios in the 40-60 per cent range play an important role in our analysis. In this category, the distribution of credit contracts between program and no program is more even: indeed, 
more bonds are issued under a program than when there is no program. Finally, when external debt exceeds 60 percent of GDP, countries once again limit their international borrowing. When they do borrow, loans and bonds are equally prevalent.

\section{Patterns of Borrowing}

In this section, we analyze the borrowing decision and the choice between bank loans and bonds. The first probit equation (Table 3) estimates the correlates of borrowing by sovereign, non-sovereign/public, and private entities in each country-quarter. The second equation reports the likelihood of bond issuance rather than a bank transaction. Throughout we report the change in the probability for an infinitesimal change in each independent, continuous variable at its mean and the discrete change in the probability for dummy variables. Standard errors are adjusted for clustering since the number of borrowing transactions varies from country to country. ${ }^{25}$ Explanatory variables include issuer characteristics (in this regression, the borrower type, with sovereign as the omitted category), global variables (U.S. growth, the swap rate, EMBI volatility), and a vector of country characteristics. $^{26}$

Among the global variables, U.S. growth appears to facilitate borrowing, especially by bond issuers in the medium-debt range (with a debt/GDP ratio between 40 and 60 percent). An interpretation is that global growth acts as collateral that supports additional borrowing. If the average monthly growth of U.S. industrial production rises

\footnotetext{
${ }^{25}$ This same correction for clustering is made throughout.

${ }^{26}$ More detail on variable definitions and sources can be found in the appendix, below.
} 
from its mean of 0.3 percent to 0.4 percent, the probability of borrowing increases by just over one percent. ${ }^{27}$

Higher volatility of J.P. Morgan's Emerging Market Bond Index, reflecting greater uncertainty about pricing, is associated with reduced borrowing. If daily volatility increases from its monthly mean of 2 per cent to 3 per cent, the probability of borrowing declines by $1 \frac{1 / 2}{2}$ to 2 percent.

Higher bond-market volatility also lowers the frequency of bond issuance relative to bank loans by borrowers from countries with debt/GDP ratios below 60 percent. ${ }^{28} \mathrm{~A}$ one percentage point increase in daily volatility reduces the likelihood of bond issuance relative to a bank transaction by $2 \frac{1}{2}-4$ percent. An interpretation is that sort-run liquidity concerns and financial market disorder are more likely to generate strategic uncertainty among bondholders, who may then withdraw to the sidelines on the fear that others are doing the same. In contrast, banks, which are better able to coordinate among themselves, are more likely to continue lending. ${ }^{29}$

Improved credit quality (proxied by Institutional Investor credit ratings, which run from a low of 0 to a high of 100) allows for more borrowing both from banks and on bond markets. The importance of the credit rating increases when the external-debt/GDP ratio exceeds 40 percent. An increase in rating by 10 points from a mean of 52 strongly

\footnotetext{
${ }^{27}$ The measure of US growth used in the regressions is the average of monthly growth rates in the quarter in which the transaction occurred.

${ }^{28}$ Where debt ratios are higher, such compositional shifts are not statistically significant. ${ }^{29}$ The Korean crisis in 1997-8, and other similar episodes, remind us that there may be limits to such coordination. But an important fact about the Korean crisis is that, in the end, the banks did roll over their loans, albeit at high interest rates. See for example Goldstein (1998).
} 
raises the likelihood of borrowing with no apparent shift in its composition. ${ }^{30}$ An interpretation is that whereas ratings influence the willingness of lenders to lend, a country's demand for foreign exchange determines how much it wishes to borrow. Thus, a higher ratio of debt service to exports increases the demand for external resources, thereby raising the likelihood of international borrowing, provided that the debt/GDP ratio is below 60 percent. Interestingly, as the debt/GDP ratio rises, the demand for external borrowing is increasingly met through loans. Similarly, when countries face higher export volatility, they are less likely to borrow abroad; in particularly, they are especially prone to reduce their borrowing on bond markets.

Bond issues tend also to be larger and longer in term. Whereas the average maturity of loans in our sample is $4 \frac{1}{2}$ years (the median is just over 3 years), that for bonds is $61 / 4$ years (with a median of 5 years). ${ }^{31}$

IMF programs have limited influence on aggregate borrowing by countries at low debt levels, as already suggested by Table 2 . Presumably structural problems that limit the ability to borrow also cause countries to seek Fund assistance. Table 3 suggests, however, that such borrowers are more likely to issue bonds than borrow from banks. In the medium-debt range, a Fund program raises the probability of borrowing by 14 per cent. At high debt levels, the influence of IMF programs remains positive, although the effect is not statistically significant.

We also distinguish precautionary programs. A first case is where IMF programs are designated as precautionary at outset. Country authorities declare that they do not

${ }^{30}$ The likelihood of borrowing rises by between 16 and 25 percent

${ }^{31}$ A borrower wishing to increase the length of maturity from the average from the average bank loan to the average bond maturity is about 3.5 percent $\left(1.75^{*} 0.02\right)$ more likely to issue a bond. 
intend to draw on resources made available. ${ }^{32}$ Borrowing via both loans and bonds is lower in such cases, but mainly for countries in the intermediate debt range. There is thus some suggestion in the data that countries choosing to approach the Fund for precautionary reasons also behave conservatively in their borrowing from banks and on bond markets.

A second case is when programs turn precautionary. In this instance the member stops drawing on resources available through the program but continues to pay the commitment fee to retain access. Aggregate borrowing does not appear to be affected by such arrangements. ${ }^{33}$

\section{The Pricing of Loans and Bonds}

To analyze pricing, we use the model developed by Eichengreen and Mody (2000, 2001) and extended by Mody and Saravia (2003). The spreads equation is linear of the form:

$$
\log (\operatorname{spread})=\beta X+u_{1}
$$

where the dependent variable is the logarithm of the spread; $X$ is a vector of issue, issuer, and period characteristics; and $u_{l}$ is a random error. $X$ contains a dummy variable for the existence of an IMF program, program characteristics if any, and interactions between the program and country characteristics. ${ }^{34}$ Since the spread will be observed only when there

\footnotetext{
${ }^{32}$ This declaration is not binding, as noted above.

${ }^{33}$ Although borrowers from countries with high debt/GDP ratios appear to be less likely to issue bonds.

${ }^{34}$ As discussed below.
} 
is a decision to borrow and lend, we correct for sample selection. Assume that spreads are observed when a latent variable $B$ crosses a threshold $B^{\prime}$ defined by:

$$
B^{\prime}=\gamma Z+u_{2}
$$

where $Z$ is the vector of variables that determines the desire of borrowers to borrow and the willingness of lenders to lend (and will also contain the IMF program variables and their interactions). $u_{2}$ is a second error term. We assume that: $u_{1} \sim N(0, \sigma), u_{2} \sim N(0,1)$, and $\operatorname{corr}\left(u_{1}, u_{2}\right)=\rho$. This is a sample selection model à la Heckman (1979). Equations (1) and (2) can be estimated simultaneously by maximum likelihood.

Estimating the determinants of market access requires information on nonborrowers. As noted above, for each country we consider three categories of issuers: sovereign, other public, and private. For each quarter and country where one of these issuers did not come to the market, we record a zero, and where they did we record a one. $^{35}$

We use our measure of repeat borrowing, $R$, to proxy for private monitoring. It is likely that the incremental information declines as $R$ rises. Moreover, since $R$ is correlated with the number of debt obligations outstanding, a larger value of $R$ may also create greater coordination problems in the event of restructuring. ${ }^{36}$

\footnotetext{
${ }^{35}$ Leung and $\mathrm{Yu}(1996)$ note that the estimation does not require the variables in the selection equation and the spread equation to be different but rather that the variables not be concentrated in a small range and that truncated observations (no bond issuance) not dominate. We do include in the selection equation (the probit), the ratio of debt service to exports, which appears to influence the issuance decision but not the determination of spreads.

${ }^{36}$ In the regressions, we use the $\log$ of $R$, which has a distribution that is much closer to normal than the (skewed) distribution of $R$. We also allow all coefficients-and not just the variables of immediate interest, $R$ and the IMF program dummy — to vary by debt category.
} 
The IMF dummy appears in both the selection and spreads equations. In contrast, $R$ appears only in the spreads equation. Other variables in the selection equation are the global and country variables from Table 3 . In addition, transaction-specific variables such as the maturity and amount of the credit transaction and dummy variables for the currency of issue and production sector of issuer (not shown to conserve space) are included in the spreads equation. ${ }^{37}$ Results are in Table 4.

U.S. growth is associated with lower spreads and raises the likelihood of borrowing through banks and bond markets. This is again consistent with the idea that stronger global growth and export opportunities act as collateral for emerging markets. These effects are especially important for the middle debt group: an increase in monthly growth rate of 0.1 percent (a 1.2 percent increase in annual growth) reduces loan spreads in the mid-debt range by 2 per cent and bond spreads in that same range by about 4 per cent. Increases in issuance probabilities are somewhat smaller.

Among the global variables, an increase in EMBI volatility has a particularly important quantitative effect on bond issuance when a country's debt-to-GDP ratio is below 60 per cent. If daily volatility rises by one per cent (at the daily mean of 2 per cent), bond issuances fall by between 5 and 7 per cent (in that same debt range). Improved credit ratings raise the probability of borrowing while lowering spreads, consistent with the idea that their main effect is to increase investors' willingness to lend. A 10-point improvement in the Institutional Investor rating has a large impact on spreads (with the largest effect in the mid-debt range, 32 per cent for loans and 48 per cent for bonds). For borrowers from countries with debt/GDP ratios below 60 per cent, improved

\footnotetext{
${ }^{37}$ For a more extended discussion of the joint interpretation of the selection and spreads equation, see Eichengreen and Mody (2000).
} 
credit ratings have a relatively small impact on bank lending, suggesting that public rating information, while relevant to access in both markets, is less valuable for bank decision making under normal circumstances.

Our main result is that repeat borrowing reduces spreads on syndicated loans, while IMF programs reduce spreads in bond markets. The coefficient on the log of repeat bank borrowing is negative, significant and larger than the corresponding coefficient for bond markets. This is true for each of the three debt/GDP categories. The effects in the loan market are large. A second loan reduces spreads by about 10 per cent. ${ }^{38}$ A third loan has a spread about 6 per cent lower than the second loan, after which the impact declines to low levels. In bond markets, in contrast, only lightly indebted countries gain from repeat borrowing.

IMF programs, on the other hand, reduce spreads and enhance access mainly in bond markets. This effect is most evident in medium-debt countries with debt/GDP ratios in the $40-60$ per cent range. ${ }^{39}$ Bond issuance by countries in this category is about 13 per cent higher when there is a Fund program and spreads are 40 per cent lower. Evidently, bondholders become more willing to lend to such countries following the negotiation of a Fund program. IMF programs also facilitate bank borrowing by countries in this medium-debt range, but the impact on spreads is insignificant.

Finally, as noted in Table 2, in the low-debt range (especially when the debt/GDP ratio is below 30 per cent), countries with IMF programs borrow little. Countries with

\footnotetext{
${ }^{38}$ A coefficient on the log of repeated borrowing of 0.14 times the difference between $\log$ 2 and $\log 1,0.69$.

${ }^{39}$ This finding of a strong impact of Fund programs for bond market access is also a central result in Mody and Saravia (2003).
} 
modest debts that nonetheless negotiate IMF programs appear to have unobserved

characteristics that raise rather than lower spreads. ${ }^{40}$

In sum, repeat transactions have a significant effect mainly on bank borrowing, while IMF programs improve the terms of access to a greater extent for bonds.

\section{Extensions}

We now explore further the robustness of these results, varying the cutoff points, considering the size of IMF programs, and distinguishing private and public borrowers.

We first ask whether the results are sensitive to cut-off points for the debt/GDP ratio. Table 5 reports results for overlapping debt/GDP ratios, starting with the 10 to 30 per cent range and then raising the end points by 10 percentage points over 6 intervals. ${ }^{41}$ Panel A, for loans, confirms the value of repeat borrowing which is significant in all 6 intervals. Comparison with the corresponding coefficients in Panel B shows that the value of repeat borrowing is greater for loans than for bonds in every debt category. Panel A also confirms that IMF programs do not reduce spreads significantly and are associated with higher spreads until the debt/GDP ratio is between 40 and 50 per cent. However, once the debt/GDP ratio exceeds 50 per cent, IMF programs are associated with a higher frequency of borrowing from banks with no apparent adverse effect on spreads.

\footnotetext{
${ }^{40}$ Even more for loans than bonds.

${ }^{41}$ Ending with the 60 to 80 per cent range. We exclude the low and high ends of the debt/GDP spectrum where outliers tend to drive the results. Thus, for example, some of the transition countries had very low levels of debt in the mid-1990s, which may not have been an accurate reflection of their external obligations.
} 
Panel B confirms that repeated bond issuance lowers spreads only in the 10-30 per cent debt/GDP range and has limited value thereafter, in fact raising spreads as if a multiplicity of bonds creates coordination problems. The contrasting importance of IMF programs is also evident. At the low end of the debt/GDP range, there is a tendency for Fund programs to be neutral or to reduce spreads modestly, but the effect strengthens noticeably as the debt/GDP ratio approaches 40-60 per cent. Beyond that, the influence of IMF programs on spreads falls. Fund programs are also associated with more bond issuance. This effect is strongest when indebtedness is between 20 and 60 per cent of $\mathrm{GDP}^{42}$

In Table 6 we examine the influence of the size of IMF programs. ${ }^{43}$ We interact the IMF program dummy with the country's debt/GDP ratio and normalize the amount of IMF lending by the country's external debt. For bonds, all the action is in the intermediate debt category where, as above, IMF programs have their major impact on spreads. The results in Table 6 thus reinforce the earlier finding that higher debt/GDP levels reduce the impact of IMF programs on bond markets. At the same time, the amount of lending does not influence spreads. These results are consistent with the Fund's value as a monitor rather than a provider of liquidity that prevents the occurrence of a financial crisis on account of strategic uncertainty among creditors.

In the market for bank loans, the larger is IMF assistance the higher are spreads in the two low-debt categories at least. Thus, while availability of additional IMF resources

\footnotetext{
${ }^{42}$ These results support those obtained by Mody and Saravia (2003).

${ }^{43}$ Based on the findings reported in Tables 4 and 5 we again allow for the effect of programs and repeat borrowing to vary by the level of indebtedness. But to avoid excessively detailed results, we return to presenting results by three debt categories.
} 
allows for additional borrowing, it is as if the creditor coordination advantage is

eliminated. $^{44}$

In Table 7 we again consider precautionary programs. For bank loans and to a lesser extent for bonds, programs that are precautionary at outset reduce both issuance and spreads, as if countries entering such programs are more cautious in seeking access to private markets. ${ }^{45}$ Spreads show a tendency to decline, as if lenders wish to acquire more of their debt because their credit quality is perceived favorably.

But programs that turn precautionary tend not to have an impact on the frequency of either bank loans or bond issuance. However, they do have a spread-reducing effect. This is largest for countries in the high-debt zone. In this range borrowers both from banks and on the bond market enjoy lower spreads, although the impact is larger in bond markets. Thus, when a country is coming off a period during which it has relied on official finance, a continued precautionary relationship with the Fund appears to enhance market access. That the relationship rather than the amount lent is what matters supports the idea of a Fund monitoring/country signaling function. ${ }^{46}$

Finally, Table 8 considers whether the market access of private borrowers is differentially affected by the existence of an IMF program. In fact, repeat borrowing reduces spreads more strongly for bank loans than bonds irrespective of whether the borrower is a private- or public-sector entity. But the effect is larger for private sector

\footnotetext{
${ }^{44}$ However, in the medium-debt range, the adverse effects of increasing debt levels from 40 to 60 percent of GDP are mitigated by the presence of an IMF program.

${ }^{45}$ Recall that this was what was suggested by our earlier analysis.

${ }^{46}$ That this function is important also to bank lenders when a country is in the high-debt range suggests that bank monitoring may not be enough when there is a high risk of insolvency.
} 
borrowers. $^{47}$ Less is publicly known about private borrowers. Their repeat borrowing therefore provides particularly valuable information in the syndicated loan market. In the bond market, in contrast, better-known private borrowers gain little from repeat borrowing. In fact, public borrowers face rising spreads as they borrow more, presumably reflecting the dominance of coordination effects over information gains.

The stronger influence of IMF programs when borrowing occurs through the bond market survives splitting the sample. Again, private borrowers gain the most. The principal action is still in the intermediate debt category. In addition, the effects for private borrowers are substantially stronger than those for public borrowers. A Fund program reduces bond spreads for private borrowers from countries in this intermediate debt zone by 47 per cent while raising the probability of bond issuance by 27 per cent. ${ }^{48}$

\section{Conclusions}

Bank loans and bonds are alternative ways of transferring capital to emerging markets. The growth of global bond markets is of course one of the signal features of the last 15 years of international financial history. Transacting through bond markets has advantages for investors, notably greater scope for diversifying country risk. Given the advance of securitization across a broad front, it is therefore important to observe that bank finance continues to play an important role in international financial markets. Bank loans are easier to access for borrowers new to such markets, since banks have a

\footnotetext{
${ }^{47}$ Thus, a second loan reduces the spreads charged private bank borrowers by about 13 percent, while public borrowers achieve, on average, a 7 percent spread reduction. ${ }^{48}$ The direction of influence is the same for public issuers, but the size and statistical significance of the outcome is weaker.
} 
comparative advantage in bridging information asymmetries. Banks' intermediation technologies are also better suited to providing small loans.

We show in this paper how the ability of banks to bridge information asymmetries is supported by repeat borrowing. As borrowers return for credit, they reveal information about themselves, reducing uncertainty and incurring a lower risk premium on their loans. Since the issuers of bonds are better known, the value of information obtained through repeat issuance is less. Indeed, to the extent that it results in a proliferation of separate bond issues, repeat borrowing may in fact increase the risk premium, reflecting the greater difficulty of coordinating the holders of different issues in the event of debtservicing difficulties.

These observations have obvious relevance to arguments about IMF monitoring and surveillance. Our results suggest that IMF monitoring and surveillance matter more in bond markets. This role for the IMF has the largest impact when debts reach 40 per cent of GDP and countries are therefore vulnerable to liquidity shocks. However, as debts continue rising from there, the impact of monitoring declines. There being relatively little uncertainty about the nature of the problem, lenders now care mainly about whether the IMF is providing real resources that help to keep debt service current. But as debt and insolvency risk grow still higher, even significant amounts of additional official finance may not make a difference. At that point, what matters most is when programs turn precautionary, signaling that conditions have improved sufficiently that the country no longer requires financial assistance.

The approach taken here points to the importance of distinguishing international capital flows by instrument and intermediary. Macroeconomic analyses lumping together 
bank loans and bonds tend to neglect important differences between these market segments stemming from the nature of the information environment, the monitoring technology, and the scope for creditor coordination. We have shown in this paper that these distinctions are important for understanding the impact of IMF programs. We would conjecture that they are equally important for understanding a variety of other issues in international finance. 


\section{References}

Bolton, Patrick and Olivier Jeanne, 2003, "Structuring and Restructuring Sovereign Debt: The Role of Seniority," Unpublished.

Bordo, Michael, Ashoka Mody, and Nienke Oomes, 2004, "Keeping Capital Flowing: The Role of the IMF," Unpublished.

Bulow, Jeremy and Kenneth Rogoff, 1989, "A Constant Recontracting Model of Sovereign Debt,” Journal of Political Economy 97, pp.155-178.

Chui, Michael, Prasanna Gai and Andrew Haldane, 2002, "Sovereign Liquidity Crises: Analytics and Implications for Public Policy," Journal of Banking and Finance, 26, pp. 519-546.

Corsetti, G., A. Dasgupta, S. Morris and H.S. Shin, 2001, "Does One Soros Make a Difference? A Theory of Currency Crises with Large and Small Traders," Review of Economic Studies, forthcoming.

Cottarelli, Carlo, and Curzio Giannini, 2002, "Bedfellows, Hostages, or Perfect Strangers? Global Capital Markets and the Catalytic Effect of IMF Crisis Lending," IMF Working Paper No. 02/193 (Washington: International Monetary Fund).

Diamond, Douglas, 1984, "Financial Intermediation and Delegated Monitoring," Review of Economic Studies 51: 393-414.

Eaton, Jonathan and Mark Gersovitz, 1981, "Debt with Potential Repudiation," Review of Economic Studies 48, pp.289-309.

Edwards, Sebastian, 1986, "The Pricing of Bonds and Bank Loans in International Markets: An Empirical Analysis of Developing Countries' Foreign Borrowing," European Economic Review 30 (3): 565-589.

Eichengreen, Barry and Ashoka Mody, 1998, "Lending booms, reserves, and the sustainability of short-term debt: inferences from the pricing of syndicated loans," Journal of Development Economics 63 (1): 5-44.

Eichengreen, Barry and Ashoka Mody, 2000, "What Explains Changing Spreads on Emerging Market Debt?" In Sebastian Edwards, ed., Capital Flows and The Emerging Economies: Theories, Evidence, and Controversies (Chicago: The University of Chicago Press). 
Eichengreen, Barry and Ashoka Mody, 2001, "Bail-Ins, Bail-Outs, and Borrowing Costs," IMF Staff Papers, Vol. 47, pp.155-87.

Eichengreen, Barry, Kenneth Kletzer and Ashoka Mody, 2004, "Crisis Resolution: Next Steps," Brookings Trade Forum 2003, Washington, DC: The Brookings Institution, pp. 279-352.

Fama, Eugene, 1985, “What's Different about Banks?” Journal of Monetary Economics 15: 29-36.

Gai, Prasanna and Nicholas Vause, 2003, "Sovereign Debt Workouts with the IMF as Delegated Monitor - A Common Agency Approach," Bank of England Working Paper no. 187.

Goldstein, Morris, 1998, The Asian Financial Crisis, Washington, D.C.: Institute of International Economics.

Heckman, James, 1979, "Sample Selection Bias as a Specification Error," Econometrica, Vol. 47, pp.153-161.

International Monetary Fund, 1999, "Involving the Private Sector in Forestalling and Resolving Financial Crises," (Washington: International Monetary Fund). Available via Internet. http://imf.org.

James, Christopher, 1987, "Some Evidence on the Uniqueness of Banks," Journal of Financial Intermediation 19: 217-235.

Jeanne, Olivier, 2001, "Sovereign Debt Crises and the International Financial Architecture, IMF working paper. (unpublished).

Kletzer, Kenneth, 2003, "Sovereign Bond Restructuring: Collective Action Clauses and Official Crisis Intervention." Paper for Bank of England conference, "The Role of the Official and Private Sectors in Resolving International Financial Crises," July 23 and 24, 2002, revised.

Kletzer, Kenneth and B. D. Wright, 2000, "Sovereign Debt as Intertemporal Barter," American Economic Review 90, pp. 621-639.

Leung, S. F., and S. Yu, 1996, "On the Choice between Sample Selection and Two-Part Models," Journal of Econometrics, Vol. 72, pp. 197-229.

Marchesi, Silvia and Jonathan Thomas, 1999, "IMF Conditionality as a Screening Device," Economic Journal, 109, pp. 111-125. 
Mody, Ashoka and Diego Saravia, 2003, "Catalyzing Capital Flows: Do IMF-Supported Programs Work as Commitment Devices?” IMF Working Paper WP/03/100, Washington D.C.

Morris, Stephen and Hyun Song Shin, 2003, "Catalytic Finance: When Does It Work?" Yale University, Cowles Foundation Discussion Paper No. 1400, February.

Pattillo, Catherine, Helene Poirson and Luca Ricci, 2004, "Through What Channels Does External Debt Affect Growth?” Brookings Trade Forum 2003, Washington, DC: The Brookings Institution, pp. 229-277.

Penalver, Adrian, 2004, "How Can the IMF Catalyse Private Capital Flows? A Model," Bank of England Working Paper no. 215.

Petersen, Mitchell A. and Raghuram Rajan, 1994, "The Benefits of Lending Relationships: Evidence from Small Business Data,” Journal of Finance 49: 3-37.

Petersen, Mitchell A. and Raghuram Rajan, 1995, "The Effect of Credit Market Competition on Lending Relationships," Quarterly Journal of Economics 110: 407-443.

Reinhart, Carmen, Kenneth S. Rogoff, and Miguel A. Savastano, 2003, "Debt Intolerance," Brookings Papers on Economic Activity, 1 (Spring): 1-74.

Rochet, Jean-Charles and Xavier Vives, 2002, "Coordination Failures and the Lender of Last Resort: Was Bagehot Right After All?” CEPR Discussion Paper no. 323.,

Tirole, Jean, 2002, Financial Crises, Liquidity and the International Financial System, Princeton, NJ: Princeton University Press. 
Table 1: Trends in International Bond and Bank Lending

\begin{tabular}{crrrrrr}
\hline & \multicolumn{3}{c}{ Number of Transactions } & & \multicolumn{2}{c}{$\begin{array}{c}\text { Aggregate Value of Transactions } \\
\text { (US \$ billions) }\end{array}$} \\
\hline Year & Bonds & Loans & Total & Bonds & Loans & Total \\
\hline 1991 & 81 & 209 & 290 & 10 & 24 & 34 \\
1992 & 177 & 252 & 429 & 21 & 18 & 39 \\
1993 & 357 & 376 & 733 & 45 & 27 & 73 \\
1994 & 307 & 508 & 815 & 39 & 40 & 79 \\
1995 & 369 & 750 & 1,119 & 48 & 56 & 104 \\
1996 & 522 & 1,066 & 1,588 & 81 & 83 & 164 \\
1997 & 555 & 1,248 & 1,803 & 100 & 125 & 225 \\
1998 & 234 & 550 & 784 & 52 & 62 & 114 \\
1999 & 334 & 402 & 736 & 65 & 47 & 113 \\
2000 & 284 & 532 & 816 & 59 & 81 & 141 \\
2001 & 290 & 470 & 760 & 78 & 62 & 140 \\
2002 & 219 & 384 & 603 & 63 & 44 & 107 \\
\hline \multirow{2}{*}{ Total } & 3,729 & 6,747 & 10,476 & 661 & 669 & 1,331 \\
\hline
\end{tabular}


Table 2: Number of Transactions, by Debt Category and IMF Program

Type of Credit

None

Bonds

Loans

\begin{tabular}{|c|c|c|}
\hline \multirow[b]{3}{*}{ None } & \multicolumn{2}{|c|}{ Debt/GDP Range (30-40 percent) } \\
\hline & No Program & IMF Program \\
\hline & 501 & 190 \\
\hline Bonds & 680 & 453 \\
\hline \multirow[t]{3}{*}{ Loans } & 1375 & 240 \\
\hline & \multicolumn{2}{|c|}{ Debt/GDP Range (40-60 percent) } \\
\hline & No Program & IMF Program \\
\hline None & 670 & 500 \\
\hline Bonds & 380 & 595 \\
\hline \multirow[t]{3}{*}{ Loans } & 999 & 775 \\
\hline & \multicolumn{2}{|c|}{ Debt/GDP Range (more than 60 percent) } \\
\hline & No Program & IMF Program \\
\hline None & 471 & 679 \\
\hline Bonds & 151 & 169 \\
\hline \multirow[t]{3}{*}{ Loans } & 309 & 344 \\
\hline & \multicolumn{2}{|c|}{ Full Sample } \\
\hline & No Program & IMF Program \\
\hline None & 2,949 & 1,758 \\
\hline Bonds & 2,455 & 1,274 \\
\hline Loans & 5,289 & 1,458 \\
\hline
\end{tabular}

Debt/GDP Range (0-30 percent)

\begin{tabular}{cc}
\hline No Program & IMF Program \\
\hline 1,301 & 389 \\
1,244 & 57 \\
2,606 & 99 \\
\hline
\end{tabular}


Table 3: The Decision to Borrow and the Choice between Bonds and Loans

\begin{tabular}{|c|c|c|c|c|c|c|}
\hline & $(1)$ & (2) & $(3)$ & $(4)$ & $(5)$ & $(6)$ \\
\hline & \multicolumn{2}{|c|}{ Debt/GDP $<=0.40$} & \multicolumn{2}{|c|}{$0.40<$ Debt/GDP $<=0.60$} & \multicolumn{2}{|c|}{ Debt/GDP>0.60 } \\
\hline & $\begin{array}{l}\text { To } \\
\text { borrow or } \\
\text { not to } \\
\text { borrow }\end{array}$ & $\begin{array}{l}\text { Bond } \\
\text { versus } \\
\text { loan }\end{array}$ & $\begin{array}{l}\text { To } \\
\text { borrow or } \\
\text { not to } \\
\text { borrow }\end{array}$ & $\begin{array}{l}\text { Bond versus } \\
\text { loan }\end{array}$ & $\begin{array}{l}\text { To borrow } \\
\text { or not to } \\
\text { borrow }\end{array}$ & $\begin{array}{l}\text { Bond } \\
\text { versus loan }\end{array}$ \\
\hline \multirow[t]{2}{*}{ lamount } & & 0.103 & & 0.095 & & 0.130 \\
\hline & & {$[2.38]^{*}$} & & {$[5.78]^{* *}$} & & {$[6.45]^{* *}$} \\
\hline \multirow[t]{2}{*}{ maturity } & & 0.020 & & 0.021 & & 0.020 \\
\hline & & {$[2.48]^{*}$} & & {$[3.46]^{* *}$} & & {$[3.99]^{* *}$} \\
\hline \multirow[t]{2}{*}{ US Industrial Growth } & 2.242 & -2.405 & 11.433 & 4.283 & 5.643 & 23.516 \\
\hline & [1.29] & {$[0.69]$} & {$[2.07]^{*}$} & {$[0.82]$} & {$[0.87]$} & {$[2.44]^{*}$} \\
\hline \multirow[t]{2}{*}{ Log of Swap Rate } & -0.062 & -0.170 & -0.051 & -0.023 & -0.135 & -0.303 \\
\hline & {$[2.10]^{*}$} & {$[1.40]$} & {$[0.83]$} & {$[0.42]$} & [1.33] & {$[3.77]^{* *}$} \\
\hline \multirow[t]{2}{*}{ EMBI volatility } & -1.367 & -3.757 & -1.478 & -2.449 & -2.021 & -0.984 \\
\hline & {$[3.68]^{* *}$} & {$[4.67]^{* *}$} & {$[1.85]$} & {$[2.46]^{*}$} & {$[1.82]$} & {$[0.88]$} \\
\hline \multirow[t]{2}{*}{ Credit Rating } & 0.005 & -0.002 & 0.016 & 0.002 & 0.025 & -0.001 \\
\hline & {$[3.00]^{* *}$} & {$[0.39]$} & {$[3.60]^{* *}$} & {$[0.56]$} & {$[5.31]^{* *}$} & {$[0.28]$} \\
\hline \multirow[t]{2}{*}{ Debt/GDP } & 0.332 & -0.430 & -1.094 & -0.739 & -0.207 & -0.113 \\
\hline & [1.44] & {$[1.51]$} & {$[2.15]^{*}$} & [1.57] & {$[0.70]$} & {$[0.34]$} \\
\hline \multirow[t]{2}{*}{ Debt Service/Exports } & 0.682 & 0.509 & 0.416 & 0.284 & 0.164 & -0.770 \\
\hline & {$[5.17]^{* *}$} & {$[2.89]^{* *}$} & {$[2.21]^{*}$} & {$[2.70]^{* *}$} & {$[0.44]$} & {$[3.38]^{* *}$} \\
\hline \multirow[t]{2}{*}{ Real GDP growth } & 0.639 & -5.670 & 3.174 & 1.330 & 0.880 & 2.058 \\
\hline & {$[0.49]$} & {$[1.70]$} & {$[1.81]$} & {$[0.50]$} & {$[0.26]$} & {$[0.72]$} \\
\hline \multirow[t]{2}{*}{ Export Volatility } & -0.309 & -0.663 & -0.974 & -0.252 & 0.133 & 0.011 \\
\hline & {$[2.56]^{*}$} & {$[1.90]$} & {$[3.20] * *$} & [1.33] & {$[0.71]$} & {$[0.12]$} \\
\hline \multirow[t]{2}{*}{ Short-term/Total Debt } & -0.163 & -0.099 & 0.331 & 0.035 & -0.387 & -0.165 \\
\hline & [1.17] & {$[0.43]$} & {$[1.05]$} & {$[0.14]$} & {$[1.06]$} & {$[0.57]$} \\
\hline \multirow[t]{2}{*}{ Reserves/Imports } & -0.011 & 0.035 & 0.009 & -0.027 & 0.043 & 0.106 \\
\hline & {$[0.67]$} & {$[0.92]$} & {$[0.29]$} & {$[0.64]$} & {$[1.00]$} & {$[3.81]^{* *}$} \\
\hline \multirow[t]{2}{*}{ Reserves/ST Debt } & -0.016 & -0.029 & -0.014 & -0.008 & -0.075 & -0.013 \\
\hline & {$[1.72]$} & {$[1.34]$} & {$[1.44]$} & {$[0.54]$} & {$[2.07]^{*}$} & {$[0.36]$} \\
\hline \multirow[t]{2}{*}{ Private Credit/GDP } & 0.071 & 0.071 & -0.044 & 0.009 & -0.068 & -0.097 \\
\hline & {$[3.44]^{* *}$} & {$[2.19]^{*}$} & {$[0.67]$} & {$[0.23]$} & {$[1.02]$} & [1.96] \\
\hline \multirow[t]{2}{*}{ Public Issuer } & 0.218 & -0.393 & 0.104 & -0.316 & 0.100 & -0.477 \\
\hline & {$[4.90]^{* *}$} & {$[4.90]^{* *}$} & {$[1.91]$} & {$[6.64]^{* *}$} & {$[1.42]$} & {$[5.24]^{* *}$} \\
\hline \multirow[t]{2}{*}{ Private Issuer } & 0.424 & -0.457 & 0.312 & -0.514 & 0.303 & -0.688 \\
\hline & {$[6.80]^{* *}$} & {$[5.07] * *$} & {$[5.87] * *$} & {$[7.17] * *$} & {$[3.66] * *$} & {$[4.44]^{* *}$} \\
\hline \multirow[t]{2}{*}{ IMF Program } & 0.027 & 0.290 & 0.141 & -0.024 & 0.084 & -0.008 \\
\hline & {$[0.54]$} & {$[3.29]^{* *}$} & {$[3.45]^{* *}$} & {$[0.36]$} & {$[1.02]$} & {$[0.14]$} \\
\hline \multirow[t]{2}{*}{ Precautionary } & -0.069 & -0.073 & -0.184 & 0.131 & -0.047 & -0.061 \\
\hline & {$[1.08]$} & {$[0.32]$} & {$[1.97]^{*}$} & {$[1.50]$} & {$[0.23]$} & {$[0.72]$} \\
\hline \multirow[t]{2}{*}{ Turned Precautionary } & -0.007 & -0.011 & 0.032 & 0.153 & 0.135 & -0.196 \\
\hline & {$[0.13]$} & {$[0.06]$} & {$[0.50]$} & {$[1.68]$} & {$[0.72]$} & {$[4.44]^{* *}$} \\
\hline Pseudo R-squared & 0.20 & 0.44 & 0.33 & 0.24 & 0.29 & 0.42 \\
\hline Observations & 8505 & 6681 & 3874 & 2721 & 1976 & 965 \\
\hline
\end{tabular}

The values reported represent the probability for an infinitesimal change in each independent, continuous variable (at its mean) and the discrete change in the probability for dummy variables. Robust $\mathrm{z}$ statistics (based on country clusters) in brackets, * significant at 5\%; ** significant at $1 \%$ 
Table 4: Pricing of Loans and Bonds

\begin{tabular}{|c|c|c|c|c|c|c|}
\hline & (1) & (2) & (3) & (4) & (5) & (6) \\
\hline \multirow[b]{2}{*}{ Debt/GDP range } & \multicolumn{3}{|c|}{ Loans } & \multicolumn{3}{|c|}{ Bonds } \\
\hline & Low & Medium & High & Low & Medium & High \\
\hline & \multicolumn{6}{|c|}{ Spread Equation } \\
\hline \multirow[t]{2}{*}{ Log of Amount } & -0.105 & -0.095 & -0.084 & 0.033 & 0.000 & -0.001 \\
\hline & {$[8.24]^{* *}$} & {$[2.91]^{* *}$} & {$[3.10]^{* *}$} & [1.04] & {$[0.01]$} & {$[0.02]$} \\
\hline \multirow[t]{2}{*}{ Maturity } & 0.040 & 0.008 & 0.012 & 0.014 & 0.008 & 0.012 \\
\hline & {$[5.34]^{* *}$} & {$[0.86]$} & {$[0.62]$} & {$[2.98]^{* *}$} & [1.02] & {$[2.00]^{*}$} \\
\hline \multirow[t]{2}{*}{ US Industrial Growth } & -6.521 & -17.801 & -8.075 & -11.756 & -36.014 & -3.713 \\
\hline & {$[0.92]$} & {$[2.08]^{*}$} & {$[0.63]$} & {$[1.23]$} & {$[3.06]^{* *}$} & {$[0.21]$} \\
\hline \multirow{2}{*}{ Log of Swap Rate } & 0.258 & 0.005 & 0.263 & 0.246 & 0.263 & -0.060 \\
\hline & {$[4.24]^{* *}$} & {$[0.06]$} & {$[1.40]$} & {$[3.51]^{* *}$} & [1.91] & {$[0.32]$} \\
\hline \multirow[t]{2}{*}{ EMBI volatility } & -1.521 & -0.202 & 3.481 & -0.995 & 7.180 & -0.303 \\
\hline & {$[2.73] * *$} & {$[0.12]$} & {$[1$.} & {$[0.60]$} & {$[1.53]$} & {$[0.12]$} \\
\hline \multirow[t]{2}{*}{ Credit Rating } & -0.017 & -0.032 & -0.022 & -0.034 & -0.048 & -0.018 \\
\hline & {$[4.07]^{* *}$} & {$[2.81]^{* *}$} & {$[2.70]^{* *}$} & {$[10.31]^{* *}$} & {$[5.00]^{* *}$} & {$[0.92]$} \\
\hline \multirow[t]{2}{*}{ Debt/GDP } & -0.472 & -0.821 & 0.222 & 0.097 & 0.675 & 4.157 \\
\hline & {$[1.22]$} & {$[0.84]$} & {$[0.50]$} & {$[0.19]$} & {$[0.60]$} & {$[2.60]^{* *}$} \\
\hline \multirow[t]{2}{*}{ Real GDP growth } & -6.479 & -11.443 & -5.028 & -10.008 & -9.887 & -4.641 \\
\hline & {$[2.36]^{*}$} & {$[3.04]^{* *}$} & {$[0.97]$} & {$[3.05]^{* *}$} & {$[2.99] * *$} & [1.53] \\
\hline \multirow{2}{*}{ Export Volatility } & -0.336 & -0.702 & 0.137 & -0.218 & 0.678 & -0.161 \\
\hline & {$[0.54]$} & [1.83] & [0.99] & {$[0.48]$} & {$[0.54]$} & {$[1.60]$} \\
\hline \multirow[t]{2}{*}{ Short-term/Total Debt } & -0.214 & 0.267 & 0.252 & -0.038 & -0.851 & 0.574 \\
\hline & [1.17] & {$[0.47]$} & {$[0.81]$} & [0.19] & {$[1.20]$} & {$[1.54]$} \\
\hline \multirow[t]{2}{*}{ Reserves/Imports } & 0.006 & 0.059 & -0.050 & 0.018 & 0.074 & 0.038 \\
\hline & {$[0.25]$} & {$[0.98]$} & {$[0.75]$} & {$[0.67]$} & {$[1.85]$} & {$[0.74]$} \\
\hline \multirow[t]{2}{*}{ Private Credit/GDP } & -0.007 & 0.047 & -0.037 & 0.033 & -0.060 & -0.260 \\
\hline & {$[0.16]$} & {$[0.78]$} & {$[0.55]$} & {$[0.84]$} & {$[0.57]$} & {$[2.23]^{*}$} \\
\hline \multirow[t]{2}{*}{ Public Issuer } & 0.086 & -0.291 & 0.197 & -0.095 & 0.247 & 0.090 \\
\hline & {$[0.42]$} & {$[0.95]$} & {$[0.58]$} & {$[0.98]$} & [1.85] & {$[0.42]$} \\
\hline \multirow[t]{2}{*}{ Private Issuer } & 0.198 & -0.162 & 0.267 & 0.195 & 0.520 & 0.599 \\
\hline & [0.87] & [0.37] & {$[0.63]$} & {$[2.25]^{*}$} & {$[3.34]^{* *}$} & [1.62] \\
\hline \multirow{2}{*}{ IMF Program } & 0.368 & -0.041 & -0.093 & 0.092 & -0.392 & -0.033 \\
\hline & {$[3.38]^{* *}$} & {$[0.27]$} & {$[1.12]$} & [1.57] & {$[2.74]^{* *}$} & {$[0.34]$} \\
\hline \multirow[t]{2}{*}{ Log of Repeat Borrowing } & -0.139 & -0.149 & -0.142 & -0.038 & 0.047 & 0.015 \\
\hline & {$[4.27]^{* *}$} & {$[3.10]^{* *}$} & {$[4.84]^{* *}$} & {$[2.56]^{*}$} & {$[1.54]$} & {$[0.45]$} \\
\hline
\end{tabular}


Table 4: Pricing of Loans and Bonds (continued: selection equation)

\begin{tabular}{|c|c|c|c|c|c|c|}
\hline & (1) & (2) & (3) & (4) & (5) & (6) \\
\hline \multirow[b]{2}{*}{ Debt/GDP range } & \multicolumn{3}{|c|}{ Loans } & \multicolumn{3}{|c|}{ Bonds } \\
\hline & Low & Medium & High & Low & Medium & High \\
\hline & \multicolumn{6}{|c|}{ Selection Equation } \\
\hline US Industrial Growth & $\begin{array}{c}7.547 \\
{[2.40]^{*}}\end{array}$ & $\begin{array}{l}14.170 \\
{[2.11]^{*}}\end{array}$ & $\begin{array}{l}2.577 \\
{[0.38]}\end{array}$ & $\begin{array}{l}2.772 \\
{[0.69]}\end{array}$ & $\begin{array}{l}13.310 \\
{[1.58]}\end{array}$ & $\begin{array}{l}13.009 \\
{[2.54]^{*}}\end{array}$ \\
\hline Log of Swap Rate & $\begin{array}{l}-0.081 \\
{[1.23]}\end{array}$ & $\begin{array}{l}-0.141 \\
{[1.41]}\end{array}$ & $\begin{array}{l}-0.066 \\
{[0.80]}\end{array}$ & $\begin{array}{c}-0.165 \\
{[2.67]^{* *}}\end{array}$ & $\begin{array}{l}-0.080 \\
{[0.99]}\end{array}$ & $\begin{array}{c}-0.240 \\
{[4.28]^{* *}}\end{array}$ \\
\hline EMBI volatility & $\begin{array}{l}-0.467 \\
{[0.78]}\end{array}$ & $\begin{array}{l}-0.061 \\
{[0.05]}\end{array}$ & $\begin{array}{l}-1.810 \\
{[2.05]^{*}}\end{array}$ & $\begin{array}{c}-6.506 \\
{[5.81]^{* *}}\end{array}$ & $\begin{array}{c}-4.992 \\
{[3.92]^{* *}}\end{array}$ & $\begin{array}{l}-1.425 \\
{[1.28]}\end{array}$ \\
\hline Credit Rating & $\begin{array}{c}0.011 \\
{[2.45]^{*}}\end{array}$ & $\begin{array}{c}0.018 \\
{[3.09]^{* *}}\end{array}$ & $\begin{array}{c}0.016 \\
{[3.88]^{* *}}\end{array}$ & $\begin{array}{c}0.008 \\
{[2.17]^{*}}\end{array}$ & $\begin{array}{c}0.017 \\
{[3.05]^{* *}}\end{array}$ & $\begin{array}{c}0.015 \\
{[5.19]^{* *}}\end{array}$ \\
\hline Debt/GDP & $\begin{array}{l}0.671 \\
{[1.42]}\end{array}$ & $\begin{array}{l}-1.441 \\
{[2.17]^{*}}\end{array}$ & $\begin{array}{l}-0.056 \\
{[0.22]}\end{array}$ & $\begin{array}{c}0.203 \\
{[0.44]}\end{array}$ & $\begin{array}{l}-1.470 \\
{[1.96]}\end{array}$ & $\begin{array}{c}0.831 \\
{[2.62]^{* *}}\end{array}$ \\
\hline Debt Service/Exports & $\begin{array}{c}0.575 \\
{[3.35]^{* *}}\end{array}$ & $\begin{array}{l}0.277 \\
{[1.46]}\end{array}$ & $\begin{array}{l}0.157 \\
{[0.47]}\end{array}$ & $\begin{array}{c}1.543 \\
{[6.25]^{* *}}\end{array}$ & $\begin{array}{c}0.643 \\
{[2.66]^{* *}}\end{array}$ & $\begin{array}{l}-0.090 \\
{[0.55]}\end{array}$ \\
\hline Real GDP growth & $\begin{array}{l}2.389 \\
{[0.71]}\end{array}$ & $\begin{array}{l}4.716 \\
{[1.82]}\end{array}$ & $\begin{array}{l}1.714 \\
{[0.51]}\end{array}$ & $\begin{array}{l}-0.281 \\
{[0.17]}\end{array}$ & $\begin{array}{l}3.829 \\
{[1.21]}\end{array}$ & $\begin{array}{l}1.239 \\
{[0.50]}\end{array}$ \\
\hline Export Volatility & $\begin{array}{l}-0.752 \\
{[2.16]^{*}}\end{array}$ & $\begin{array}{c}-1.257 \\
{[3.08]^{* *}}\end{array}$ & $\begin{array}{l}0.072 \\
{[0.48]}\end{array}$ & $\begin{array}{c}-0.585 \\
{[2.14]^{*}}\end{array}$ & $\begin{array}{l}-1.097 \\
{[2.18]^{*}}\end{array}$ & $\begin{array}{l}-0.008 \\
{[0.09]}\end{array}$ \\
\hline Short-term/Total Debt & $\begin{array}{l}-0.323 \\
{[1.23]}\end{array}$ & $\begin{array}{l}0.380 \\
{[0.85]}\end{array}$ & $\begin{array}{l}-0.141 \\
{[0.40]}\end{array}$ & $\begin{array}{l}-0.303 \\
{[0.94]}\end{array}$ & $\begin{array}{l}0.286 \\
{[0.79]}\end{array}$ & $\begin{array}{l}-0.308 \\
{[1.87]}\end{array}$ \\
\hline Reserves/Imports & $\begin{array}{l}-0.018 \\
{[0.63]}\end{array}$ & $\begin{array}{l}-0.004 \\
{[0.12]}\end{array}$ & $\begin{array}{l}0.007 \\
{[0.22]}\end{array}$ & $\begin{array}{l}-0.046 \\
{[1.01]}\end{array}$ & $\begin{array}{l}-0.009 \\
{[0.16]}\end{array}$ & $\begin{array}{l}0.034 \\
{[1.34]}\end{array}$ \\
\hline Reserves/Short-term Debt & $\begin{array}{l}-0.034 \\
{[1.91]}\end{array}$ & $\begin{array}{l}-0.025 \\
{[1.97]^{*}}\end{array}$ & $\begin{array}{l}-0.065 \\
{[1.76]}\end{array}$ & $\begin{array}{l}-0.044 \\
{[1.74]}\end{array}$ & $\begin{array}{l}-0.035 \\
{[1.89]}\end{array}$ & $\begin{array}{c}-0.056 \\
{[3.40]^{* *}}\end{array}$ \\
\hline Private Credit/GDP & $\begin{array}{l}0.104 \\
{[1.89]}\end{array}$ & $\begin{array}{l}-0.017 \\
{[0.20]}\end{array}$ & $\begin{array}{l}0.019 \\
{[0.42]}\end{array}$ & $\begin{array}{c}0.164 \\
{[5.88]^{* *}}\end{array}$ & $\begin{array}{l}-0.016 \\
{[0.26]}\end{array}$ & $\begin{array}{l}-0.066 \\
{[1.54]}\end{array}$ \\
\hline IMF Program & $\begin{array}{l}-0.077 \\
{[0.76]}\end{array}$ & $\begin{array}{l}0.115 \\
{[1.61]}\end{array}$ & $\begin{array}{l}0.090 \\
{[1.23]}\end{array}$ & $\begin{array}{c}0.168 \\
{[2.23]^{*}}\end{array}$ & $\begin{array}{l}0.132 \\
{[1.96]}\end{array}$ & $\begin{array}{l}0.041 \\
{[1.44]}\end{array}$ \\
\hline Public Issuer & $\begin{array}{c}0.591 \\
{[9.51]^{* *}}\end{array}$ & $\begin{array}{c}0.414 \\
{[6.35]^{* *}}\end{array}$ & $\begin{array}{c}0.560 \\
{[8.60]^{* *}}\end{array}$ & $\begin{array}{l}0.211 \\
{[1.76]}\end{array}$ & $\begin{array}{l}-0.142 \\
{[1.76]}\end{array}$ & $\begin{array}{c}-0.159 \\
{[2.50]^{*}}\end{array}$ \\
\hline Private Issuer & $\begin{array}{c}0.811 \\
{[11.43]^{* *}}\end{array}$ & $\begin{array}{c}0.713 \\
{[9.77]^{* *}}\end{array}$ & $\begin{array}{c}0.670 \\
{[13.07]^{* *}}\end{array}$ & $\begin{array}{c}0.365 \\
{[2.97]^{* *}}\end{array}$ & $\begin{array}{l}-0.010 \\
{[0.13]}\end{array}$ & $\begin{array}{l}-0.107 \\
{[1.38]}\end{array}$ \\
\hline Lambda & $\begin{array}{l}-0.032 \\
{[0.35]}\end{array}$ & $\begin{array}{l}0.054 \\
{[0.15]}\end{array}$ & $\begin{array}{l}0.081 \\
{[0.52]}\end{array}$ & $\begin{array}{l}-0.044 \\
{[0.60]}\end{array}$ & $\begin{array}{c}-0.657 \\
{[3.20] * *}\end{array}$ & $\begin{array}{l}0.145 \\
{[0.44]}\end{array}$ \\
\hline No. of Transactions & 4278 & 1771 & 648 & 2220 & 899 & 281 \\
\hline Observations & 6389 & 3102 & 1783 & 4510 & 2351 & 1310 \\
\hline
\end{tabular}

Robust z statistics, based on country clusters, in brackets, * significant at 5\%; ** significant at $1 \%$.

Note: Among issuer types, sovereign is the omitted category. The spreads equation also has dummy variables for sector of issuer (e.g., manufacturing, services, finance) interacted with issuer type (public, private). Also included are dummy variables for currency of issue and, for bond markets, a dummy variable for fixed rather than a floating rate of interest. In the selection equation, the values reported represent the probability for an infinitesimal change in each independent, continuous variable (at its mean) and the discrete change in the probability for dummy variables. 
Table 5A: Loans: Impact of IMF Programs and Repeat Borrowing

\begin{tabular}{lcccccc}
\hline & $(1)$ & $(2)$ & $(3)$ & $(4)$ & $(5)$ & $(6)$ \\
\hline Debt Range & $10-30$ & $20-40$ & $30-50$ & $40-60$ & $50-70$ & $60-80$ \\
(\% of GDP) & \multicolumn{7}{c}{ Spread Equation } \\
IMF Program & 0.561 & 0.230 & 0.272 & -0.041 & -0.091 & -0.081 \\
& {$[3.06]^{* *}$} & {$[2.25]^{*}$} & {$[3.53]^{* *}$} & {$[0.27]$} & {$[0.70]$} & {$[0.88]$} \\
Repeat Borrowing & -0.174 & -0.090 & -0.058 & -0.149 & -0.159 & -0.146 \\
& {$[4.89]^{* *}$} & {$[3.05]^{* *}$} & {$[2.77]^{* *}$} & {$[3.10]^{* *}$} & {$[3.99]^{* *}$} & {$[5.15]^{* *}$} \\
Selection Equation & & & \\
IMF Program & 0.120 & 0.045 & 0.041 & 0.115 & 0.162 & 0.135 \\
& {$[1.30]$} & {$[0.51]$} & {$[0.48]$} & {$[1.61]$} & {$[1.99]^{*}$} & {$[1.55]$} \\
No. of Transactions & 1908 & 2598 & 2426 & 1771 & 1355 & 571 \\
Observations & 2960 & 4066 & 3804 & 3102 & 2647 & 1471 \\
\hline
\end{tabular}

Table 5B: Bonds: Impact of IMF Programs and Repeat Borrowing

\begin{tabular}{lcccccc}
\hline & $(1)$ & $(2)$ & $(3)$ & $(4)$ & $(5)$ & $(6)$ \\
\hline $\begin{array}{l}\text { Debt Range } \\
\text { (\% of GDP) }\end{array}$ & $10-30$ & $20-40$ & $30-50$ & $40-60$ & $50-70$ & $60-80$ \\
& \multicolumn{7}{c}{ Spread Equation } \\
IMF Program & 0.034 & -0.000 & -0.043 & -0.392 & -0.252 & -0.023 \\
& {$[0.26]$} & {$[0.01]$} & {$[0.55]$} & {$[2.74]^{* *}$} & {$[1.86]$} & {$[0.20]$} \\
Repeat Borrowing & -0.067 & -0.022 & -0.004 & 0.047 & 0.067 & 0.013 \\
& {$[2.92]^{* *}$} & {$[1.50]$} & {$[0.28]$} & {$[1.54]$} & {$[2.31]^{*}$} & {$[0.39]$} \\
Selection Equation \\
IMF Program & 0.153 & 0.250 & 0.221 & 0.132 & 0.045 & 0.048 \\
& {$[1.78]$} & {$[2.90]^{* *}$} & {$[2.92]^{* *}$} & {$[1.96]$} & {$[1.05]$} & {$[1.51]$} \\
No. of Transactions & 789 & 1653 & 1539 & 899 & 580 & 272 \\
Observations & 1911 & 3227 & 3038 & 2351 & 1973 & 1212 \\
\hline
\end{tabular}

Robust z statistics, based on country clusters, in brackets, * significant at 5\%; ** significant at $1 \%$. Other variables included in these regressions are those listed in Table 4, including those referred to in the footnote to that Table. In the selection equation, the values reported represent the probability for an infinitesimal change in each independent, continuous variable (at its mean) and the discrete change in the probability for dummy variables. 
Table 6: Does the Amount of IMF Lending Matter?

\begin{tabular}{|c|c|c|c|c|c|c|}
\hline & (1) & (2) & (3) & (4) & (5) & (6) \\
\hline \multirow[b]{2}{*}{ Debt/GDP range } & \multicolumn{3}{|c|}{ Loans } & \multicolumn{3}{|c|}{ Bonds } \\
\hline & Low & Medium & High & Low & Medium & High \\
\hline & \multicolumn{6}{|c|}{ Spread Equation } \\
\hline \multirow[t]{2}{*}{ IMF Program } & 0.689 & 1.623 & -0.122 & 0.270 & -2.469 & -1.052 \\
\hline & {$[1.15]$} & {$[3.74]^{* *}$} & {$[0.15]$} & {$[0.65]$} & {$[2.04]^{*}$} & {$[0.87]$} \\
\hline \multirow[t]{2}{*}{ IMF*Debt/GDP } & -1.550 & -3.818 & -0.039 & -0.737 & 4.354 & 1.393 \\
\hline & {$[0.86]$} & {$[3.98]^{* *}$} & {$[0.03]$} & [0.59] & [1.81] & [0.79] \\
\hline \multirow[t]{2}{*}{ IMF Amount/Debt } & 2.941 & 6.922 & 1.801 & 1.343 & -2.401 & 1.846 \\
\hline & {$[2.76]^{* *}$} & {$[5.05]^{* *}$} & {$[0.82]$} & [1.64] & [0.99] & [1.13] \\
\hline \multirow[t]{3}{*}{ Log of Repeat Borrowing } & -0.143 & -0.139 & -0.146 & -0.040 & 0.051 & 0.018 \\
\hline & {$[4.48]^{* *}$} & {$[3.27]^{* *}$} & {$[4.83]^{* *}$} & {$[2.64] * *$} & [1.76] & {$[0.55]$} \\
\hline & \multicolumn{6}{|c|}{ Spread Equation } \\
\hline \multirow[t]{2}{*}{ IMF Program } & -0.063 & 0.141 & 0.226 & -0.237 & 0.941 & 0.409 \\
\hline & {$[0.20]$} & {$[0.29]$} & {$[0.48]$} & {$[0.83]$} & {$[2.28]^{*}$} & [1.04] \\
\hline \multirow[t]{2}{*}{ IMF*Debt/GDP } & -0.106 & -0.371 & -0.210 & 1.245 & -2.991 & -0.689 \\
\hline & {$[0.12]$} & {$[0.38]$} & {$[0.35]$} & [1.38] & {$[2.50]^{*}$} & [1.11] \\
\hline \multirow[t]{2}{*}{ IMF Amount/Debt } & 0.386 & 4.357 & 0.033 & 0.376 & 3.047 & 1.205 \\
\hline & {$[0.32]$} & {$[3.03]^{* *}$} & {$[0.02]$} & {$[0.34]$} & {$[1.34]$} & {$[1.27]$} \\
\hline Number of Transactions & 4278 & 1771 & 648 & 2220 & 899 & 281 \\
\hline Observations & 6389 & 3102 & 1783 & 4510 & 2351 & 1483 \\
\hline
\end{tabular}

Robust z statistics, based on country clusters, in brackets, * significant at 5\%; ** significant at $1 \%$. Other variables included in these regressions are those listed in Table 4, including those referred to in the footnote to that Table. In the selection equation, the values reported represent the probability for an infinitesimal change in each independent, continuous variable (at its mean) and the discrete change in the probability for dummy variables. 
Table 7A: Bank Loans: Is Precaution Valuable?

\begin{tabular}{|c|c|c|c|c|c|c|}
\hline & (1) & (2) & (3) & (4) & (5) & (6) \\
\hline $\begin{array}{l}\text { Debt Range } \\
\text { (\% of GDP) }\end{array}$ & $10-30$ & $20-40$ & $30-50$ & $40-60$ & $50-70$ & $60-80$ \\
\hline \multicolumn{7}{|c|}{ Spread Equation } \\
\hline IMF Program & $\begin{array}{c}0.587 \\
{[2.92]^{* *}}\end{array}$ & $\begin{array}{c}0.291 \\
{[2.95]^{* *}}\end{array}$ & $\begin{array}{c}0.299 \\
{[3.15]^{* *}}\end{array}$ & $\begin{array}{l}0.086 \\
{[0.59]}\end{array}$ & $\begin{array}{l}0.151 \\
{[0.94]}\end{array}$ & $\begin{array}{c}0.206 \\
{[2.07]^{*}}\end{array}$ \\
\hline $\begin{array}{l}\text { Precautionary } \\
\text { Program }\end{array}$ & $\begin{array}{l}-0.372 \\
{[1.10]}\end{array}$ & $\begin{array}{l}-0.533 \\
{[2.12]^{*}}\end{array}$ & $\begin{array}{c}-0.125 \\
{[0.85]}\end{array}$ & $\begin{array}{l}-0.348 \\
{[2.02]^{*}}\end{array}$ & $\begin{array}{l}-0.470 \\
{[2.39]^{*}}\end{array}$ & $\begin{array}{c}-0.477 \\
{[2.79]^{* *}}\end{array}$ \\
\hline Turned Precautionary & & -0.075 & -0.022 & -0.097 & -0.264 & -0.350 \\
\hline Program & & {$[0.36]$} & {$[0.15]$} & {$[0.77]$} & {$[2.55]^{*}$} & {$[2.44]^{*}$} \\
\hline Repeat Borrowing & $\begin{array}{c}-0.174 \\
{[4.89]^{* *}}\end{array}$ & $\begin{array}{c}-0.091 \\
{[3.17]^{* *}}\end{array}$ & $\begin{array}{c}-0.059 \\
{[2.72]^{* *}}\end{array}$ & $\begin{array}{c}-0.164 \\
{[3.39]^{* *}}\end{array}$ & $\begin{array}{c}-0.186 \\
{[4.90]^{* *}}\end{array}$ & $\begin{array}{c}-0.144 \\
{[5.23]^{* *}}\end{array}$ \\
\hline \multicolumn{7}{|c|}{ Selection Equation } \\
\hline IMF Program & $\begin{array}{l}0.166 \\
{[1.88]}\end{array}$ & $\begin{array}{l}0.093 \\
{[0.92]}\end{array}$ & $\begin{array}{l}0.086 \\
{[0.88]}\end{array}$ & $\begin{array}{c}0.196 \\
{[2.69]^{* *}}\end{array}$ & $\begin{array}{c}0.250 \\
{[2.71]^{* *}}\end{array}$ & $\begin{array}{c}0.149 \\
{[2.16]^{*}}\end{array}$ \\
\hline $\begin{array}{l}\text { Precautionary } \\
\text { Program }\end{array}$ & $\begin{array}{l}-0.341 \\
{[1.68]}\end{array}$ & $\begin{array}{l}-0.172 \\
{[1.16]}\end{array}$ & $\begin{array}{l}-0.200 \\
{[1.30]}\end{array}$ & $\begin{array}{l}-0.272 \\
{[2.32]^{*}}\end{array}$ & $\begin{array}{l}-0.310 \\
{[2.07]^{*}}\end{array}$ & $\begin{array}{l}-0.177 \\
{[1.16]}\end{array}$ \\
\hline Turned Precautionary & & -0.117 & -0.055 & -0.015 & 0.026 & 0.165 \\
\hline Program & & {$[0.65]$} & {$[0.61]$} & {$[0.18]$} & {$[0.18]$} & {$[0.84]$} \\
\hline No. of Transactions & 1908 & 2598 & 2426 & 1771 & 1355 & 571 \\
\hline Observations & 2960 & 4066 & 3804 & 3102 & 2647 & 1471 \\
\hline \multicolumn{7}{|c|}{ Table 7B: Bonds: Is Precaution Valuable? } \\
\hline & (1) & (2) & (3) & (4) & (5) & (6) \\
\hline $\begin{array}{l}\text { Debt Range } \\
\text { (\% of GDP) }\end{array}$ & $10-30$ & $20-40$ & $30-50$ & $40-60$ & $50-70$ & $60-80$ \\
\hline \multicolumn{7}{|c|}{ Spread Equation } \\
\hline IMF Program & $\begin{array}{l}0.053 \\
{[0.37]}\end{array}$ & $\begin{array}{l}0.043 \\
{[0.81]}\end{array}$ & $\begin{array}{l}0.014 \\
{[0.17]}\end{array}$ & $\begin{array}{l}-0.282 \\
{[2.50]^{*}}\end{array}$ & $\begin{array}{l}0.013 \\
{[0.08]}\end{array}$ & $\begin{array}{l}0.148 \\
{[1.36]}\end{array}$ \\
\hline $\begin{array}{l}\text { Precautionary } \\
\text { Program }\end{array}$ & $\begin{array}{l}-0.198 \\
{[0.96]}\end{array}$ & $\begin{array}{l}-0.077 \\
{[0.28]}\end{array}$ & $\begin{array}{l}-0.153 \\
{[1.31]}\end{array}$ & $\begin{array}{l}-0.140 \\
{[0.98]}\end{array}$ & $\begin{array}{l}-0.283 \\
{[0.82]}\end{array}$ & $\begin{array}{c}-0.372 \\
{[3.20]^{* *}}\end{array}$ \\
\hline Turned Precautionary & & -0.131 & -0.130 & -0.267 & -0.622 & -0.331 \\
\hline Program & & {$[2.33]^{*}$} & {$[2.36]^{*}$} & {$[1.60]$} & {$[2.01]^{*}$} & {$[2.12]^{*}$} \\
\hline Repeat Borrowing & $\begin{array}{c}-0.068 \\
{[2.98]^{* *}}\end{array}$ & $\begin{array}{l}-0.023 \\
{[1.66]}\end{array}$ & $\begin{array}{l}-0.005 \\
{[0.37]}\end{array}$ & $\begin{array}{l}0.049 \\
{[1.74]}\end{array}$ & $\begin{array}{c}0.065 \\
{[2.32]^{*}}\end{array}$ & $\begin{array}{c}0.007 \\
{[0.24]}\end{array}$ \\
\hline \multicolumn{7}{|c|}{ Selection Equation } \\
\hline IMF Program & $\begin{array}{c}0.248 \\
{[2.63]^{* *}}\end{array}$ & $\begin{array}{c}0.238 \\
{[2.48]^{*}}\end{array}$ & $\begin{array}{c}0.233 \\
{[2.88]^{* *}}\end{array}$ & $\begin{array}{c}0.112 \\
{[1.99]^{*}}\end{array}$ & $\begin{array}{l}0.065 \\
{[0.94]}\end{array}$ & $\begin{array}{l}0.065 \\
{[1.45]}\end{array}$ \\
\hline Precautionary & -0.324 & -0.290 & -0.155 & -0.067 & -0.115 & -0.064 \\
\hline Program & {$[2.93]^{* *}$} & {$[2.03]^{*}$} & {$[1.75]$} & {$[0.62]$} & {$[1.06]$} & {$[0.65]$} \\
\hline Turned Precautionary & & 0.138 & 0.033 & 0.161 & 0.064 & -0.003 \\
\hline Program & & {$[1.52]$} & {$[0.32]$} & {$[1.25]$} & {$[0.47]$} & {$[0.03]$} \\
\hline No. of Transactions & 789 & 1653 & 1539 & 899 & 580 & 272 \\
\hline Observations & 1911 & 3227 & 3038 & 2351 & 1973 & 1212 \\
\hline
\end{tabular}


Robust z statistics, based on country clusters, in brackets, * significant at 5\%; ** significant at $1 \%$. Other variables included in these regressions are those listed in Table 4, including those referred to in the footnote to that Table. In the selection equation, the values reported represent the probability for an infinitesimal change in each independent, continuous variable (at its mean) and the discrete change in the probability for dummy variables. 
Table 8: Do Private Borrowers Benefit More than Public Borrowers From IMF Programs?

A: Private Borrowers

\begin{tabular}{|c|c|c|c|c|c|c|}
\hline & $(1)$ & $(2)$ & (3) & (4) & (5) & (6) \\
\hline \multirow[b]{2}{*}{ Debt/GDP range } & \multicolumn{3}{|c|}{ Loans } & \multicolumn{3}{|c|}{ Bonds } \\
\hline & Low & Medium & High & Low & Medium & High \\
\hline & \multicolumn{6}{|c|}{ Spread Equation } \\
\hline IMF Program & $\begin{array}{c}0.245 \\
{[2.25]^{*}}\end{array}$ & $\begin{array}{l}-0.116 \\
{[0.56]}\end{array}$ & $\begin{array}{l}-0.114 \\
{[1.19]}\end{array}$ & $\begin{array}{l}0.096 \\
{[1.62]}\end{array}$ & $\begin{array}{c}-0.466 \\
{[2.85]^{* *}}\end{array}$ & $\begin{array}{l}-0.031 \\
{[0.13]}\end{array}$ \\
\hline \multirow[t]{2}{*}{ Log of Repeat Borrowing } & $\begin{array}{c}-0.133 \\
{[4.14]^{* *}}\end{array}$ & $\begin{array}{c}-0.179 \\
{[2.93]^{* *}}\end{array}$ & $\begin{array}{c}-0.179 \\
{[7.08]^{* *}}\end{array}$ & $\begin{array}{c}-0.098 \\
{[4.52]^{* *}}\end{array}$ & $\begin{array}{l}-0.034 \\
{[1.33]}\end{array}$ & $\begin{array}{l}-0.103 \\
{[1.50]}\end{array}$ \\
\hline & \multicolumn{6}{|c|}{ Spread Equation } \\
\hline IMF Program & $\begin{array}{l}-0.044 \\
{[0.77]}\end{array}$ & $\begin{array}{l}0.091 \\
{[2.01]^{*}}\end{array}$ & $\begin{array}{l}0.130 \\
{[1.46]}\end{array}$ & $\begin{array}{l}0.200 \\
{[2.71]^{* *}}\end{array}$ & $\begin{array}{l}0.266 \\
{[2.51]^{*}}\end{array}$ & $\begin{array}{l}-0.018 \\
{[0.65]}\end{array}$ \\
\hline $\begin{array}{l}\text { Number of Transactions } \\
\text { Observations }\end{array}$ & 3315 & 1672 & 784 & 2109 & 890 & 452 \\
\hline
\end{tabular}

B: Public Borrowers

\begin{tabular}{lcccccc}
\hline & $(1)$ & $(2)$ & $(3)$ & $(4)$ & $(5)$ & $(6)$ \\
\hline \multirow{5}{*}{ Debt/GDP range } & \multicolumn{5}{c}{ Loans } & \multicolumn{3}{c}{ Bonds } \\
\cline { 2 - 7 } IMF Program & Low & Medium & High & Low & Medium & High \\
\cline { 2 - 7 } & \multicolumn{7}{c}{ Spread Equation } \\
\cline { 2 - 7 } Log of Repeat Borrowing & 0.599 & -0.065 & -0.038 & 0.118 & -0.153 & 0.018 \\
& {$[5.12]^{* *}$} & {$[0.50]$} & {$[0.26]$} & {$[1.34]$} & {$[1.55]$} & {$[0.22]$} \\
& -0.138 & -0.109 & -0.075 & -0.014 & 0.099 & 0.083 \\
IMF Program & {$[4.38]^{* *}$} & {$[2.10]^{*}$} & {$[1.10]$} & {$[0.61]$} & {$[2.67]^{* *}$} & {$[4.82]^{* *}$} \\
\cline { 2 - 7 } & -0.053 & 0.054 & 0.045 & 0.085 & 0.075 & 0.072 \\
Number of Transactions & {$[0.49]$} & {$[0.85]$} & {$[1.19]$} & {$[1.35]$} & {$[1.16]$} & {$[2.37]^{*}$} \\
Observations & & \multicolumn{7}{c}{ Spread Equation } & & \\
\hline
\end{tabular}

Robust z statistics, based on country clusters, in brackets, * significant at 5\%; ** significant at $1 \%$. Other variables included in these regressions are those listed in Table 4, including those referred to in the footnote to that Table. In the selection equation, the values reported represent the probability for an infinitesimal change in each independent, continuous variable (at its mean) and the discrete change in the probability for dummy variables. 


\section{Data Appendix}

\section{Bond characteristics}

The bond dataset, obtained from Loanware and Bondware covers the period 1991 to 2002 and includes: (1) launch spreads over risk free rates (in basis points, where one basis point is one-hundredth of a percentage point); (2) the amount of the issue (millions of US\$); (3) the maturity in years; (4) whether the borrower was a sovereign, other public sector entity, or private debtor; (5) currency of issue; (6) whether the bond had a fixed or floating rate; (7) borrower's industrial sector: manufacturing, financial services, utility or infrastructure, other services, or government (where government, in this case, refers to subsovereign entities and central banks, which could not be classified in the other four industrial sectors).

\section{Global variables}

(1) United States industrial production growth rate: average of month-month growth rate over a quarter. (2) United States ten-year swap spread. (3) Emerging Market Bond Index: standard deviation of difference in log of daily spreads.

\section{Country Characteristics}

\begin{tabular}{|c|c|c|c|c|}
\hline Variable & (Billions) & Periodicity & Source & Series \\
\hline $\begin{array}{l}\text { Total external debt } \\
\text { (EDT) }\end{array}$ & US\$ & Annual & WEO & $\mathrm{D}$ \\
\hline $\begin{array}{l}\text { Gross national } \\
\text { product (GNP, } \\
\text { current prices) }\end{array}$ & US\$ & Annual & WEO & NGDPD \\
\hline $\begin{array}{l}\text { Gross domestic } \\
\text { product (GDPNC, } \\
\text { current prices) }\end{array}$ & National & Annual & WEO & NGDP \\
\hline $\begin{array}{l}\text { Gross domestic } \\
\text { product (GDP90, } \\
1990 \text { prices) }\end{array}$ & National & Annual & WEO & NGDP_R \\
\hline $\begin{array}{l}\text { Total debt service } \\
\text { (TDS) }\end{array}$ & US\$ & Annual & WEO & $\overline{\mathrm{DS}}$ \\
\hline Exports (XGS) & US\$ & Annual & WEO & $\mathrm{BX}$ \\
\hline Exports $(\mathrm{X})$ & US\$ & Monthly & IFS & M\#c|70_dzf \\
\hline $\begin{array}{l}\text { Reserves } \\
\text { (RESIMF) }\end{array}$ & US\$ & Quarterly & IFS & $\mathrm{q \# c| \_ 11 \_ dzf}$ \\
\hline Imports (IMP) & US\$ & Quarterly & IFS & $\mathrm{q \# \textrm {c } | 7 1 \_ \mathrm { dzf }}$ \\
\hline $\begin{array}{l}\text { Domestic bank } \\
\text { credit } \\
(\text { CLM_PVT })^{1}\end{array}$ & National & Quarterly & IFS & $\mathrm{q \# c} \mid 32 d_{\text {__z } z f}$ \\
\hline $\begin{array}{l}\text { Short-term bank } \\
\text { debt (BISSHT) }\end{array}$ & US\$ & semi-annual & BIS & \\
\hline
\end{tabular}




\begin{tabular}{|l|l|l|l|l|}
\hline $\begin{array}{l}\text { Total bank debt } \\
(\text { BISTOT })^{3}\end{array}$ & US\$ & semi-annual & BIS & \\
\hline $\begin{array}{l}\text { Credit rating } \\
\text { (CRTG) }\end{array}$ & Scale & semi-annual & $\begin{array}{l}\text { Institutional } \\
\text { Investor }\end{array}$ & \\
\hline
\end{tabular}

Constructed Variables

\begin{tabular}{|l|l|}
\hline Debt/GNP & EDT/GNP \\
\hline Debt service/exports & TDS/XGS \\
\hline GDP/growth & $0.25 * \ln [$ GDP90_t/GDP90_\{t-1\}] \\
\hline Standard deviation of export growth & $\begin{array}{l}\text { Standard deviation of monthly growth rates } \\
\text { of exports (over six months) }\end{array}$ \\
\hline Reserves/imports & RESIMF/IMP \\
\hline Reserves/GNP & RESIMF/GNP \\
\hline Reserves/short-term debt & RESIMF/BISSHT \\
\hline Short-term debt/total debt & BISSHT/BISTOT \\
\hline Domestic credit/GDP & CLM_PVT/(GDPNC/4) \\
\hline
\end{tabular}

Sources: International Monetary Fund's World Economic Outlook (WEO) and International Financial Statistics (IFS);IMF program data from the IMF's Executive Board Documents and Staff Estimates; World Bank's World Debt Tables (WDT) and Global Development Finance (GDF); Bank of International Settlements' The Maturity, Sectoral, and Nationality Distribution of International Bank Lending. Credit ratings were obtained from Institutional Investor's Country Credit Ratings. Missing data for some countries was completed using the US State Department's Annual Country reports on Economic Policy and Trade Practices (which are available on the internet from http:www.state.gov/www/issues/economic/trade_reports/). U.S. industrial production was obtained from the Federal Reserve and Swap rates and EMBI from Bloomberg.

${ }^{1}$ Credit to private sector.

${ }^{2}$ Cross-border bank claims in all currencies and local claims in nonlocal currencies of maturity up to and including one year.

${ }^{3}$ Total consolidated cross-border claims in all currencies and local claims in nonlocal currencies. 